\title{
Implementation: Decarbonisation and Economic Growth
}

\author{
Jan-Erik Lane ${ }^{1}$ \\ ${ }^{1}$ Fellow with Public Policy Institute in Belgrade. \\ Correspondence: Jan-Erik Lane, 10 Charles Humbert, 1205 Geneva.
}

Received: March 18, 2016

Accepted: May 12, 2016

Available online: May 13, 2016

doi:10.11114/aef.v3i3.1606

URL: http://dx.doi.org/10.11114/aef.v3i3.1606

\begin{abstract}
The implementation process for the COP21 Agreement must now start in order to have any chance of succeeding with its main objective of a $40 \%$ reduction in $\mathrm{CO} 2$ emissions. Actually, this process of implementation can be imagined to go on for the entire century, as COP21 promises a carbon free economy sometime after 2050. However, policy implementation is difficult to achieve, especially in a heavily decentralised structure. It is likely that many governments will only deliver small changes in emission decreases, but keep lots of fossil fuel energy sources in order to maintain a positive rate of economic growth. Complete decarbonisation of entire societies is a figment of the imagination.
\end{abstract}

Keywords: Implementation theory, reneging, decarbonisation, energy, Sachs, Wildavsky, Williamson.

\section{Introduction}

As the COP21 Agreement comes closer to being a valid treaty under public international law, the implementation process has to begin, as time is pressing, for two reasons. On the one hand, the COP21 outlines a rapid halt and reduction in $\mathrm{CO} 2$ emissions, which requires action from state and society in the signing countries. On the other hand, the evidence about global warming is mounting, all indicating that this process is moving ahead at alarming speed.

What is at stake is a heavily decentralized process of implementation, where each governments of the signing states will chose its policy mix in order to accomplish the main objectives with COP21. It is said that there will be some form of international governance of the implementation, including periodic reviews of country results. Yet, the implementation of the halting and decrease of $\mathrm{CO} 2 \mathrm{~s}$ is basically decentralized to each country. Given the importance of the COP21, upon which the future of mankind may hinge, each state now has incentives to start elaborate a mix of policies that promote the chief objectives:

- Reversing the trend in CO2:s and also GHG:s;

- Decreasing the CO2:s by $40 \%$ until 2030;

- Eliminating the $\mathrm{CO} 2$ :s completely until the end of the century.

In this paper, I wish to make the following points:

a) Achieving these goals presents formidable tasks for governments, the business community and civil society the most important policy commitment in this century besides maintaining global peace;

b) The mix of policies will be country specific and path dependent upon how much the country now relies upon fossil fuels and what other options for energy sources are available;

c) Decarbonisation at the $40 \%$ level is bound to have repercussions for economic growth. Perhaps economist J. Sachs is correct when he claims that decarbonisation must lead to a "sustainable economic life", even if economic output would have to fall, maybe as much as $20 \%$ (Sachs, 2015).

Substantiating the points a) and b) with empirical evidence from various international agencies and their websites, I am very sceptical about the feasibility of a "sustainable economy" on the global level. It is more likely that global warming will run its dismal course, with Nature spelling out the dire consequences for mankind and its social systems of climate change.

\subsection{Concept Of Implementation: A Short Theoretical Note}

As the most gifted American political scientist of the $20^{\text {th }}$ century emphasized in his manifold writings, Aaron Wildavsky, policy implementation involves much more than ordinary public administration or governance. The central 
distinction is that between output, i.e. decisions, legislation and budgeting, on the one hand and outcome, i.e. the real results occurring in the social systems at some point in time (Pressman and Wildavsky, 1973). Redirecting political science and public administration towards policy analysis of outcomes, he was joined by scholars from other disciplines in new centres to study the actual effects of government decisions and actions, and not only its intensions or promises.

The empirical enquiries into a number of implementation processes with the national or local governments in a country revealed the occurrence of a number of surprising features, such as:

i) An often sharp distinction between intended and unintended outcomes;

ii) Unintended outcomes were often more dys-functional than eu-functional;

iii) Often important unrecognized outcomes were identified;

iv) In an implementation process, the means and the goals could be confused - goal displacement;

v) Over time, implementation proved often to be dynamic, meaning that both means and goals were reinterpreted and replaced;

vi) The concept of rational policy-making as complete and efficient achievement of stated objectives had to be questioned and the inherent difficulties in policy implementation be recognized.

Wildavsky drew the sound conclusion that policy analysts face the task of informing government, bureaucracies and civil society as well as markets about the TRUTH concerning the probability of accomplishing objectives by clearly stated means (Wildavsky). He did not, it should be pointed out, exaggerate the implementation problems into a theory of irrational behaviour - the so-called carbage can model (March and Olsen, 1976). But one must be aware of the problematic motivation with several players in an implementation process, which economist Williamson (1973) called "opportunistic behaviour with guile".

It is always underlined in teachings about international politics and public international law that enforcement is the weak link in the entire system of regulations by international organisations and treaty laws. Implementation of intra state agreements can often not be enforced, which opens up for many kinds of opportunistic behaviour: promise against compliance.

When we look at the different positions of a few states with regard to the implementation of COP21, we have to take into account both their emissions profile and the possibility of reneging. If, and I emphasize IF, a government is forced to choose between $\mathrm{CO}$ :s reduction and economic development, it may be very tempted by reneging in some form or another. Antropogenic emissions originate often with energy consumption, which is basic to the economy in a wide sense - industry, transportation, housing, construction, agriculture, etc.

\section{Energy Profiles}

The COP21 framework focuses upon CO2:s among the GHG:s, although methane may become very dangerous. In addition, the COP21 targets only certain sources of CO2:s, namely anthropogenic ones stemming from energy consumption in a wide sense. Energy is indispensable not only in the Cosmos of stars and planets, but also for all kinds of social systems of men and women. When analysing the greenhouse gases (GHG), one focuses upon the following energy sources and their emission impacts:

- Fossil fuels - strong CO2 impact

- Biofuels - weak CO2 impact

- $\quad$ Nuclear power - no $\mathrm{CO} 2$ impact

- Hydro power - no $\mathrm{CO} 2$ impact

- $\quad$ Wind power - no $\mathrm{CO} 2$ impact

- Thermal power - no $\mathrm{CO} 2$ impact.

The construction of power stations has in general a $\mathrm{CO} 2$ impact, when lots of cement is employed. However, these are the options that countries may pursue, depending upon their environment and capacity to import and export energy.

The emission consequences of these energy sources may be identified in a few global Figures, clarifying the actual global predicament concerning the real sources of $\mathrm{CO} 2$. What we want to know is how energy consumption results in emissions outcomes.

Figure 1 links CO2 emissions strongly with the burning of fossil fuels. The CO2:s constitute roughly $70 \%$ of all GHG:s, and they have been in constant increase since the latter half of the $20^{\text {th }}$ century. 


\section{Carbon emissions associated with human activity}

[Billion metric tons carbon/yr, share of total emissions]

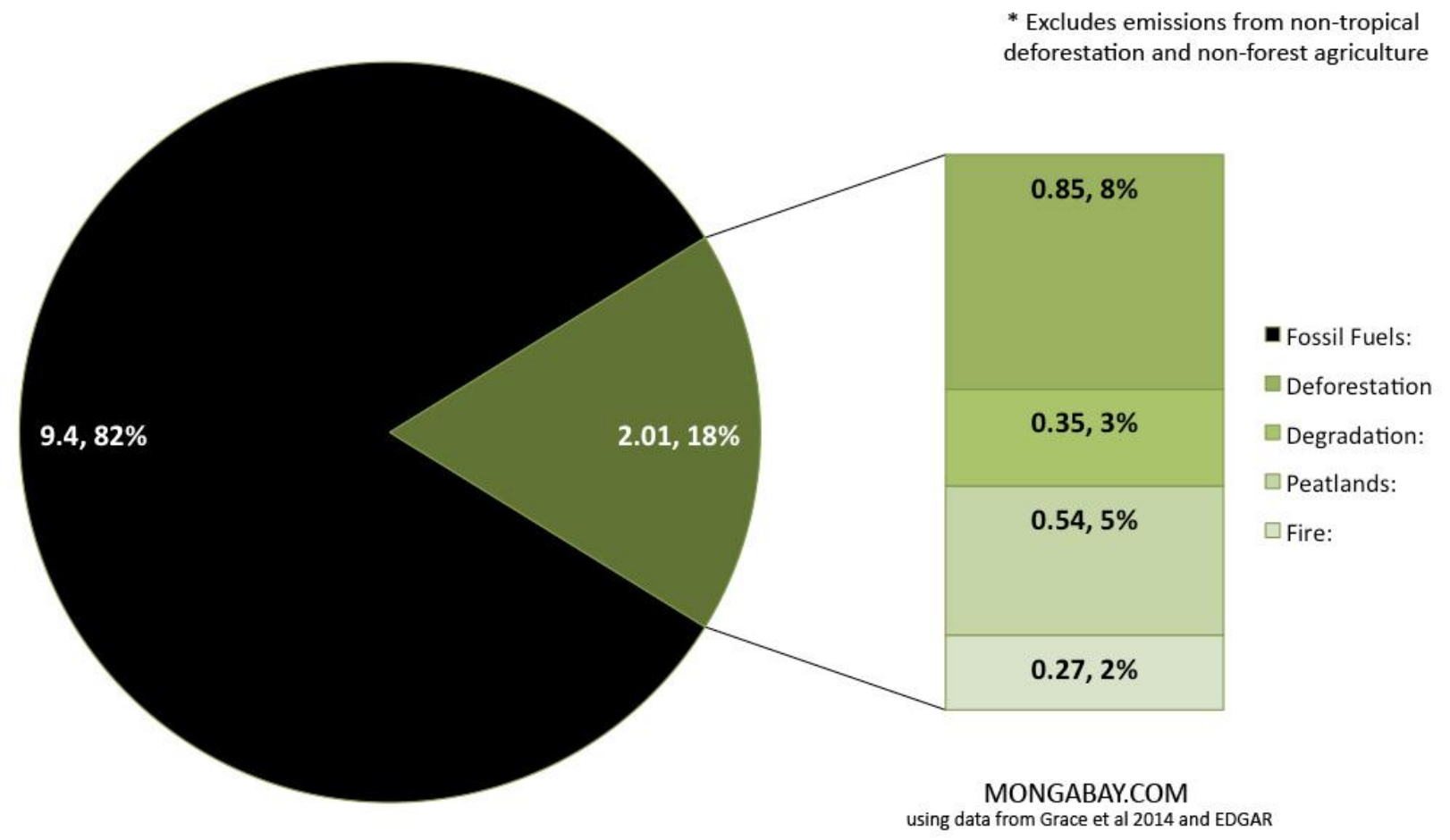

Figure 1. Global Energy Sources of CO2:s

Source: http://www.mywallpaper.top/time-lapse-history-of-human-global-co2-emissions-youtube.html.

One could point out that also renewables can result in $\mathrm{CO} 2$ :s, like the burning of wood or biomass, but people are quick to retort that bioenergy also consumes $\mathrm{CO} 2$ :s, making them neutral carbon wise.

The relevance of fossil fuels to human societies appear from Figure 2. The fossil fuels combined make up the major part of energy sources for human activities, globally speaking.

\section{Renewable}

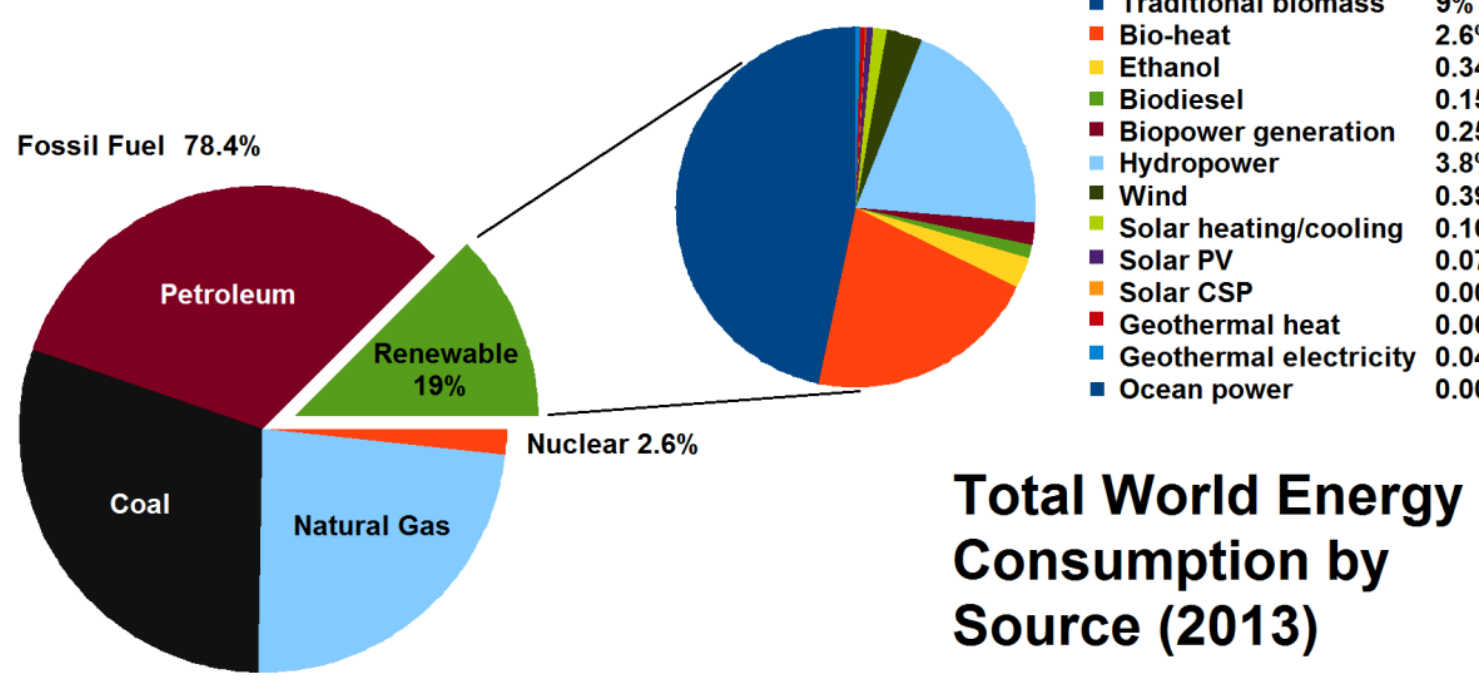

Figure 2. Energy Sources Globally

Source: http://archaeopteryxgr.blogspot.com/2015_08_01_archive.html 
Pursuing the COP21 agenda, the use of fossil fuels must be reduced. It can be done in two ways. Either one simply brings down the burning of coal, oil and natural gas, or one attempts to replace fossil fuels with nuclear power and renewables. If the goal is simply to decrease CO2:s with 40\%, in terms 1990 or 2016 consumption, then one could just close down lots of facilities, like e.g. old coal and oil fired stations and not replace them with natural gas stations.

However, there is a catch. And the crux of the matter is economic development or growth. Hitherto, energy consumption has been a major pillar for strong economic advances, especially in Asia. Does cutting the burning of fossil fuels reduce affluence and increase poverty?

\subsection{SACHS'PROBLEMATIC: Decarbonisation and sustainable economic growth}

Decarbonisation or the reduction of fossil fuels as energy sources is the policy objective favoured by the COP21 framework. However, the COP21 Agreement says little about the consequences for access to cheap energy and in turn the growth implications. Sachs is well aware of the dilemma: decarbonisation versus rapid economic development for countries aiming at a catch-up strategy. His solution is the somewhat amorphous concept of a sustainable economy.

Sachs has launched a coherent call for the world to move towards sustainable development, based on decarbonisation of the energy systems of countries (http://jeffsachs.org/2015/08/sustainable-development-for-humanitys-future/). He has correctly emphasized the close link between economic development or growth and the massive use of fossil fuels as energy sources during the last 20 years, resulting in the enormous expansion of GHG emissions. Ideally, a country would wish to start reducing its emissions of GHG:s without any major impact upon the GDP. This would require a policy mix of promoting energy efficiency, moving towards the use of renewables massively and cutting back upon fossil fuels.

The idea of a sustainable economy suffers from the same weakness as the notion of a planned economy. Who is to control the key parameters in a sustainable economy: markets or states?

\section{World GDP Growth Divided Between Energy Growth and Efficiency/Technology Growth}

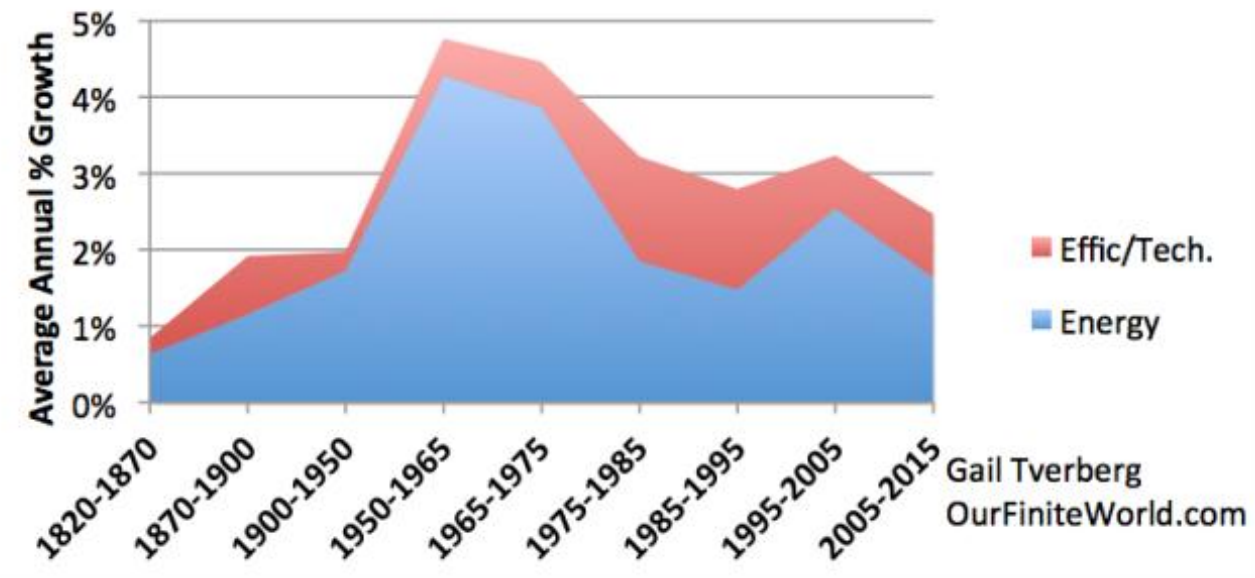

Figure 3. Energy and GDP growth

Source: http://www.zerohedge.com/news/2015-09-15/how-our-energy-problems-lead-debt-collapse-problem

\subsection{Country Scenarios}

It seems reasonable to argue that the required 40\% reduction of $\mathrm{CO} 2$ emissions from their 1990 base will prove extremely difficult to implement for most countries in the world, at least if it is to be done without cuts in economic output. Moreover, it also appears adequate to claim that countries that are heavily reliant upon fossil fuels today will face most difficulties. Thus, they may have incentive to renege one way or the other.

On the other hand, one would like to say that countries with an energy mix of both fossil fuels and renewables would have a better chance to succeed in implementing the COP21 goals, especially when they have large experience of hydro and nuclear power. Yet, countries differ much in their energy mixes, from Uruguay with almost no reliance upon fossil fuels to the Gulf States that rest almost entirely upon fossil fuels.

I will explore the variety of energy mixes in a small sample of various countries below. As Figure 3 indicates strongly, energy consumption in a wide sense is typical of every sector of society and it has consequences for $\mathrm{CO} 2$ emissions, 
according to Figures 1 and 2. I will relate the country emissions to its GDP development and explore the different energy mixes. First, we have the emerging economies with a close link between emissions and GDP, e.g. the BRICS. Second, the contrast to emerging economies is the set of mature economies, where one may find a decoupling of emissions and GDP growth. Third, there is the so-called green states that speak much of their sustainable strategy, but that is maybe only talking. Finally, in poor states there is bound to be lots of fossil fuels burning.

\subsection{Catch-Up Countries}

Several countries adhere to the label "emerging economies". Here, I look at China, India, Brazil and South Africa among the BRICS, plus Thailand and Malaysia as well as Iran.

\subsubsection{China}

One finds that the emissions of $\mathrm{CO} 2$ :s follows economic development closely in many countries, like China, South Koreas and most Latin American countries. The basic explanation is population growth and GDP growth - more people breathing and searching for higher life style. Take the case of China, whose emissions are the largest in the world, totally speaking (Figure 4). Interestingly, China has begun a fundamental change of its energy policy in 2015, reacting to mostly domestic demands for cleaner air and environment.

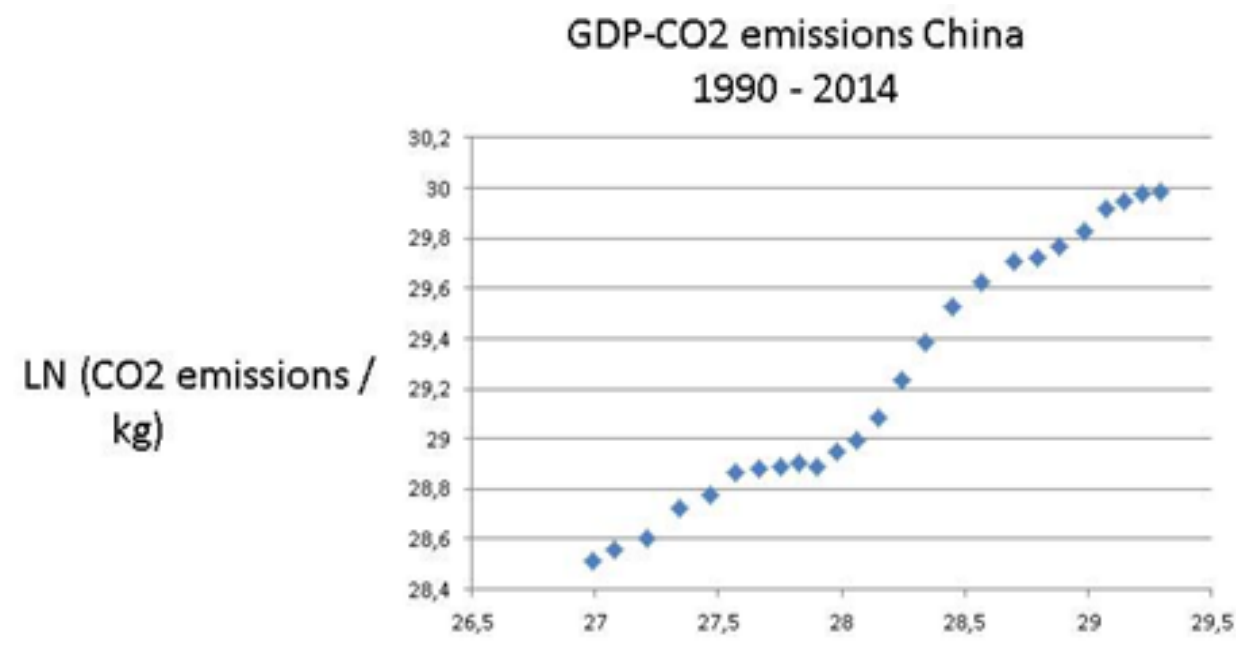

\section{LN (GDP / Constant Value 2005 USD)}

Figure 4. CHINA: LN (CO2/ Kg and LN (GDP / Constant Value 2005 USD) $\left(y=0,7 x ; R^{2}=0,97\right)$

The sharp increase in $\mathrm{CO}$ :s in China reflects not only the immensely rapid industrialization and urbanization of the last 30 years, but also its problematic energy mix (Figure 5), which is now up for overhaul.

\section{China energy consumption 2014}

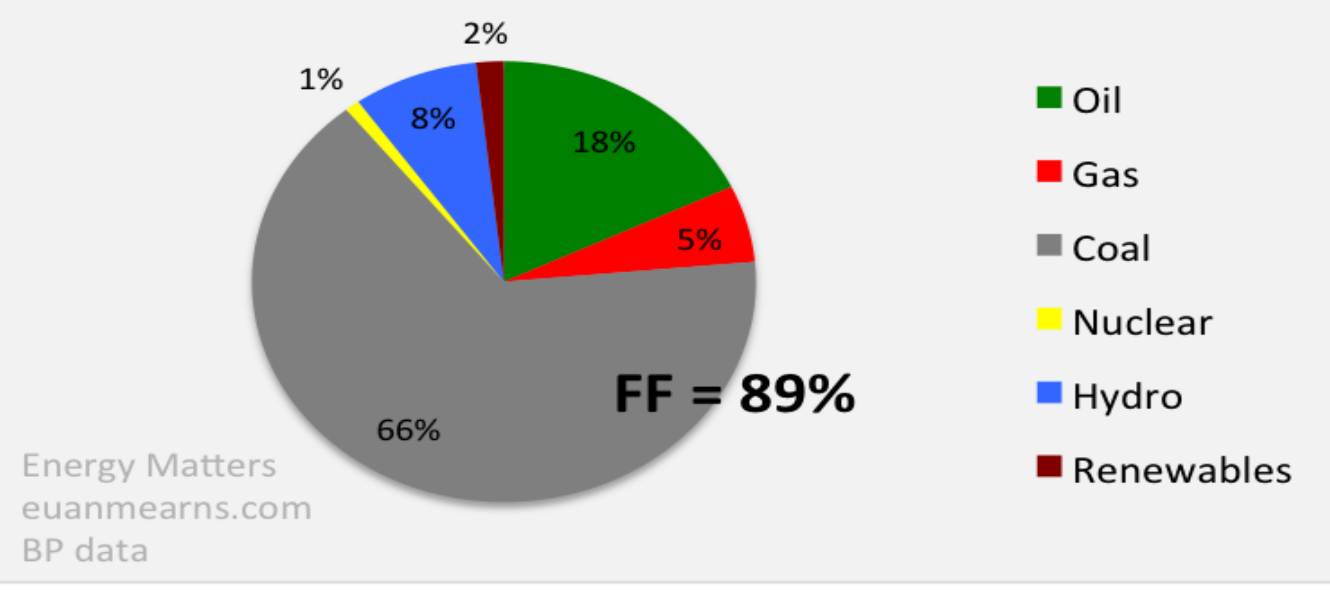

Figure 5.

Source: http://euanmearns.com/china-post-industrial-revolution/ 
Almost 70 per cent of the energy consumption comes from the burning of coal with an additional 20 per cent from other fossil fuels. The role of nuclear and renewable energy sources with the exception of hydro power is very small indeed. This energy mix makes China very vulnerable to demands for radically cutting $\mathrm{CO} 2$ emissions: use other energy sources or massive installation of highly improved filters for carbon capture? It is true that China has turned to wind power, solar power and nuclear power massively recently, but the task of achieving a $40 \%$ reduction is enormous. China evidently hopes to respect its COP2 1 commitments while still enjoying an economic growth rate of above 5\%, but it is realistic? New coal plants have actually been opened recently, replacing out-dated old ones in order to propel growth.

It should be pointed out that several small countries have much higher emissions per capita than China. This raises the enormously difficult problematic of fair cuts of emissions. Should the largest polluters per capita like the rich Gulf States cut most or the biggest aggregate polluters, like emerging economies China, India and Indonesia for instance? At COP21 this issue about redistribution was resolved by the creation of a super fund to assist energy transition and environment protection in developing counties, as proposed early by economist Stern (2007)

\subsubsection{India}

India will certainly appeal to the same problematic, namely per capita or aggregate emissions. The country is even more negative than China to cut $\mathrm{CO} 2$ emissions, as it is in an earlier stage of industrialization and urbanization. Figure 6 shows the close connection between emissions and GDP for this giant nation.

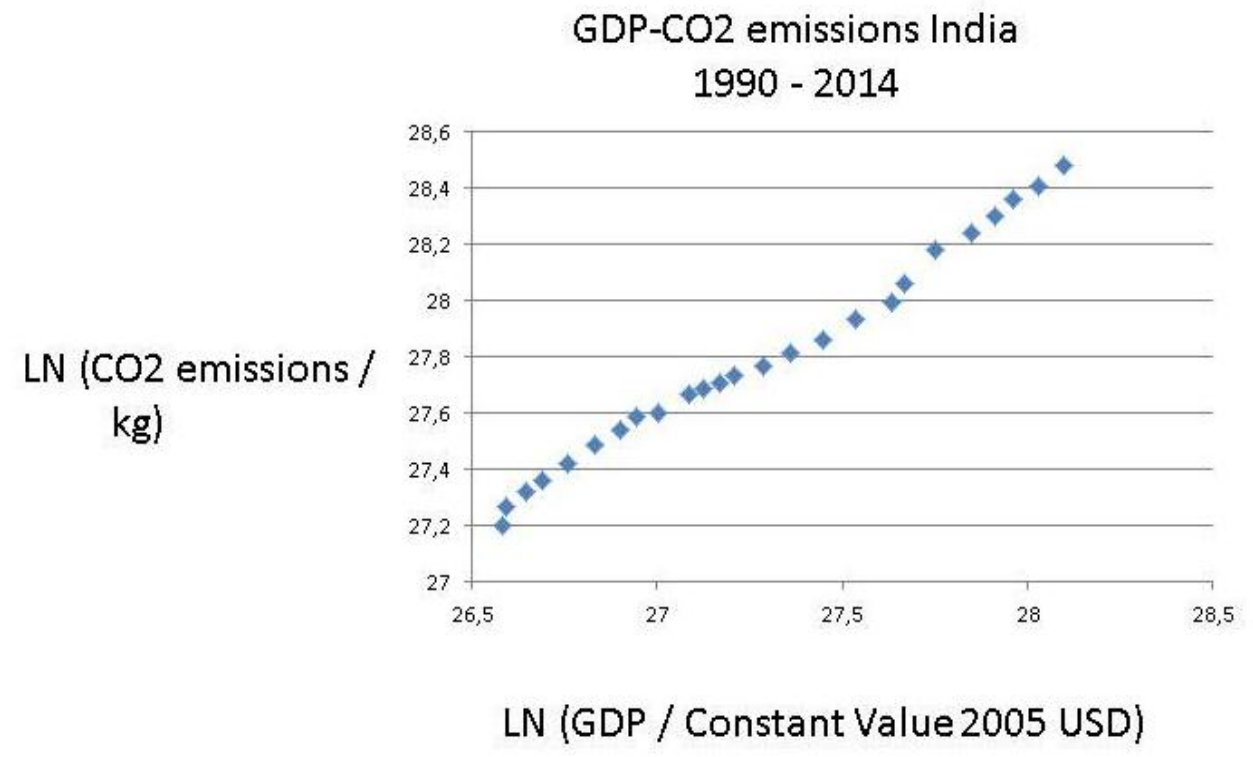

Figure 6. India: LN (CO2/ Kg And LN (GDP / Constant Value 2005 USD)

$$
\left(y=0,77 x+6,79 ; R^{2}=0,99\right)
$$

India needs cheap energy for its industries, transportation and heating as well as air-conditioning (Figure 6), meaning it aims strongly at electrification. From where will this power come? India has water power and nuclear energy, but relies most upon coal, oil and gas as power source. It has strong ambitions for the future expansion of energy, but how is it to be generated, the world asks. India actually has one of smallest numbers for energy per capita, although it produces much energy totally. Figure 7 shows its energy mix where renewables play a bigger role than in China. However, the renewables in India may lead to deforestation and considerable pollution. 

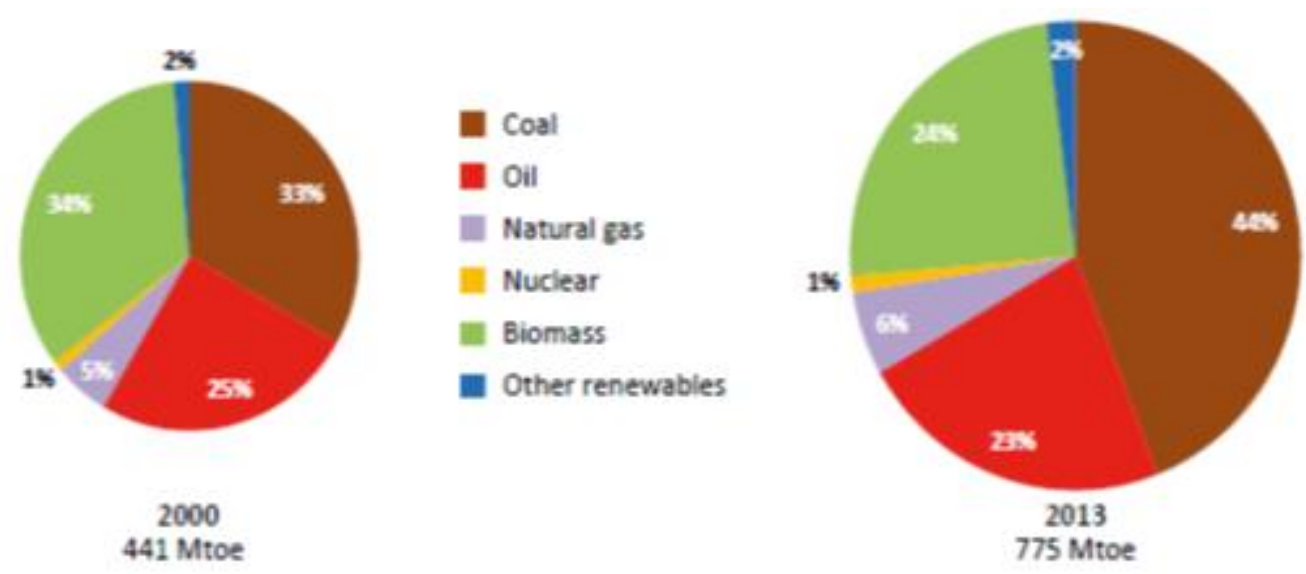

Figure 7.

Source: http://www.eia.gov/beta/international/analysis.cfm?iso=IND

India needs especially electricity, as 300 million inhabitants lack access to it. The country is heavily dependent upon fossil fuels (70 per cent), although to a much lesses extent than China. Electricity can be generated by hydro power and nuclear power, both of which India employs. Yet, global warming reduces the capacity of hydro power - water shortages - and nuclear power meets with political resistance. Interestingly, India uses much biomass and waste for electricity production, which does not always reduce $\mathrm{CO} 2$ emissions. India's energy policy will be closely watched by other governments and NGO:s after 2018. The constant tension between the demand for economic growth on the one hand and environmental protection on the other hand is sharply portrayed in Ramesh (2015).

\subsubsection{Thailand}

One may guess correctly that countries that try hard to "catch-up" will have increasing emissions. This was true of China and India. Let us look at three more examples: Thailand, Malaysia and Iran - all emerging economies. Figure 8 begins with Thailand that has become a major car producer.

GDP vs. CO2 emissions Thailand 1990-2014

$\mathrm{LN}$

(CO2 emissions
$/ \mathrm{kg}$ )

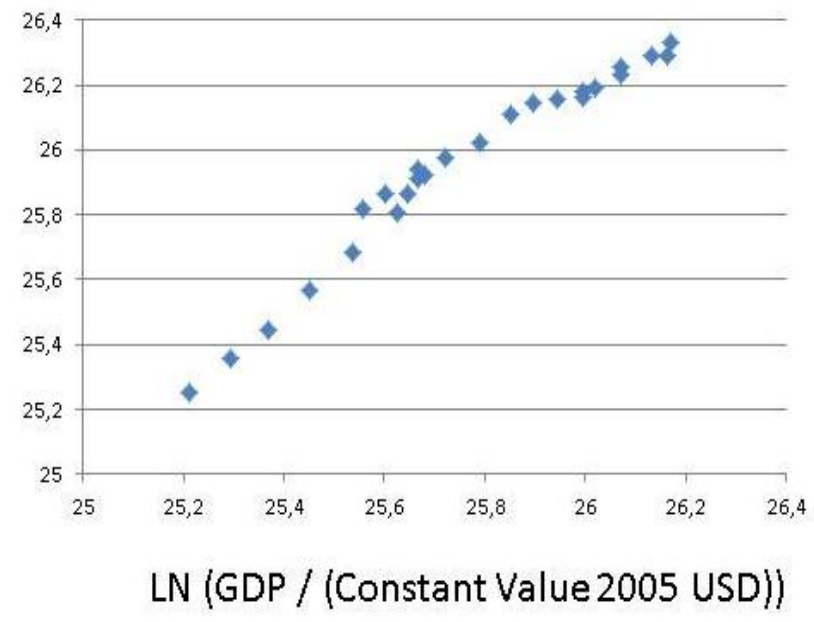

Figure 8. Thailand $\left(\mathrm{Y}=1,07 \mathrm{x}, \mathrm{R}^{2}=0,96\right)$

The CO2 emissions in Thailand are quite high, reflecting the economic advances in South East Asia. The trend is up and up. Can it be reversed without serious economic impact? Figure 9 shows the energy mix of this dynamic country, economically. 


\section{Total energy consumption in Thailand, by type (2010)}

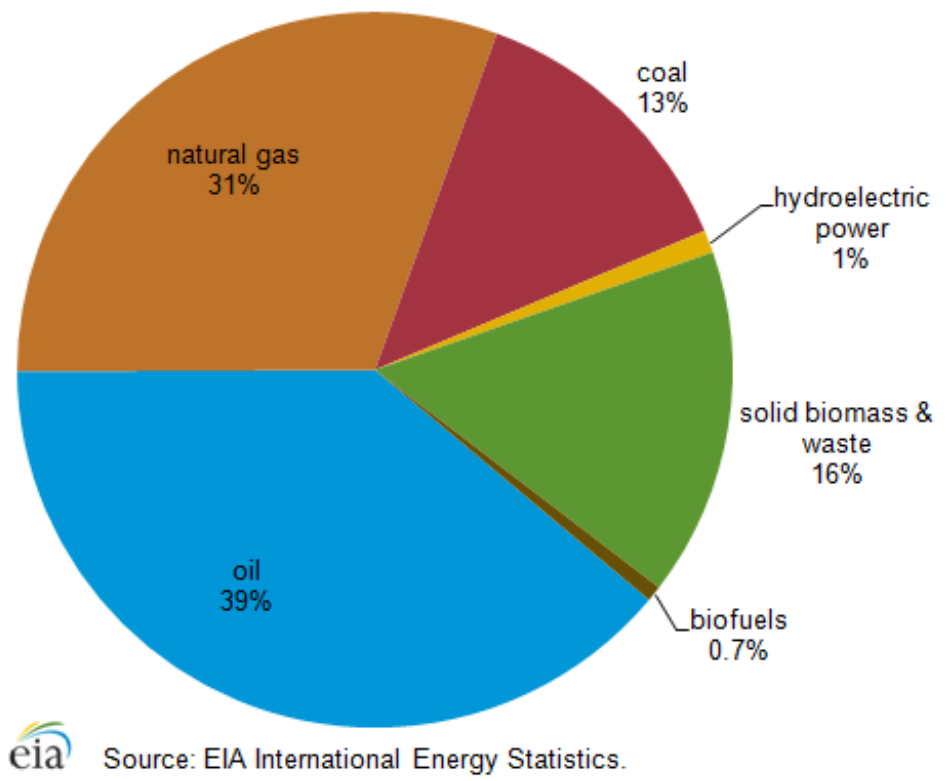

Figure 9.

The reliance upon fossil fuels is high, or over $80 \%$ of energy consumption coming from the burning of coal, oil and natural gas. Hydro power is marginal, but bio-energy plays a major role, but it is really not carbon neutral. Thailand needs to come up with far-reaching reforms of its energy sector in order to comply with COP21 objectives.

\subsubsection{Malaysia}

The overall situation - fossil fuels dependency - is the same for Malaysia as for Thailand. And the CO2:s are high, following the GDP trend (Figure 10).

GDP vs. CO2 emissions Malaysia 1990-2014
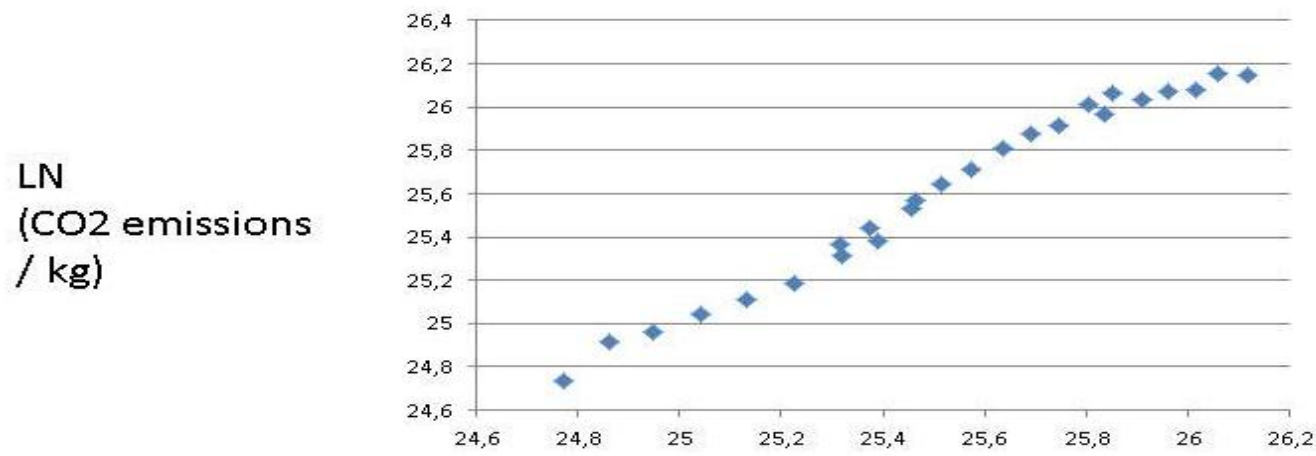

LN (GDP / (Constant Value 2005 USD))

Figure 10. Malaysia $\left(y=1,13 x ; R^{2}=0,98\right)$

Yet, Malaysia employs energy of a very mixed bag (Figure 15), but still its emissions augment in line with economic development. There may be a planning out of the growth trend in emissions recently, but Malaysia use very little of carbon neutral energy sources. There is hydro power, but the country must move to solar and wind power rapidly. 


\section{MALAYSIA'S ENERGY MIX}

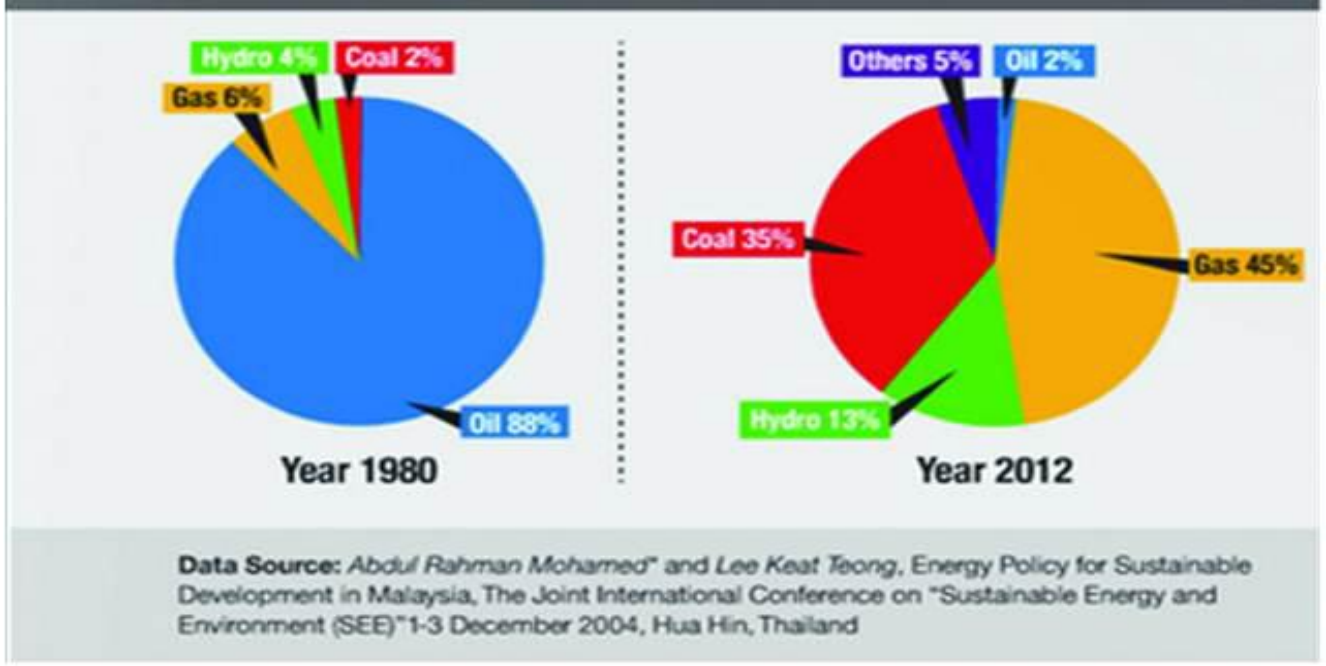

Figure 11.

Renewables are not a major element in the energy consumption mix of Malaysia, as fossil fuels dominate, but not coal luckily.

\subsubsection{Iran}

Countries may rely upon petroleum and gas mainly - see Iran (Figures 12 and 13). CO2 emissions have generally followed economic development in this giant country, although there seems to be a planning out recently, perhaps due to the international sanctions against its economy.

GDP vs. CO2 emissions Iran 1990-2014
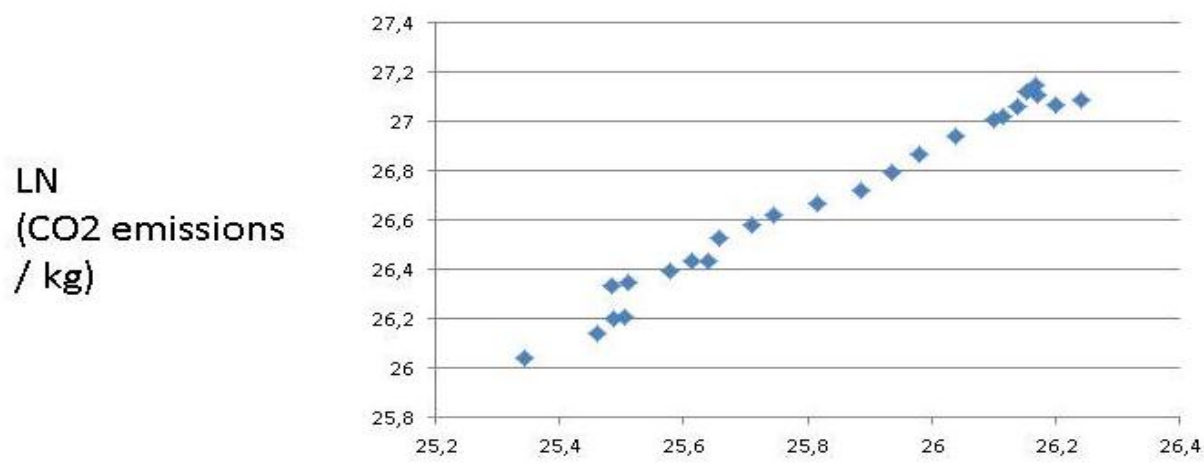

LN (GDP / (Constant Value 2005 USD))

Figure 12. $\operatorname{Iran}\left(y=1,22 \mathrm{x}-4,91 ; \mathrm{R}^{2}=0,98\right)$

Iran is together with Russia and Qatar the largest owner of natural gas deposits. But despite using coal in very small amounts, its $\mathrm{CO} 2$ emissions are high. Natural gas pollute less than oil and coal, but if released unburned it is very dangerous as a greenhouse gas. 


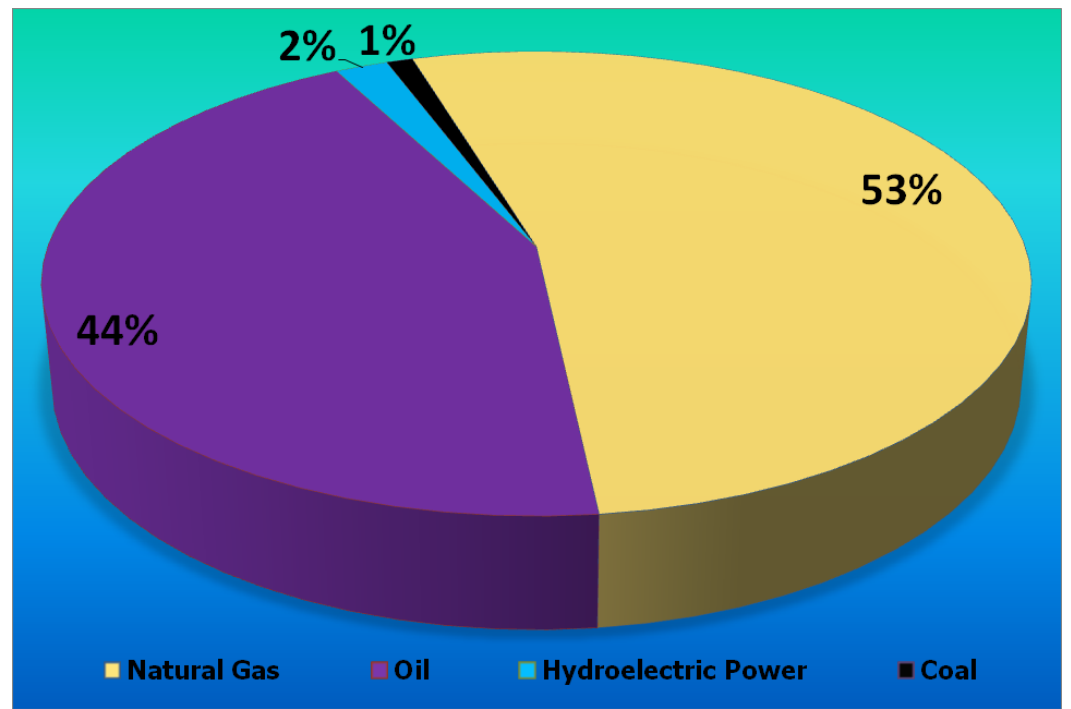

Figure 14.

\subsubsection{Brazil}

Let us now look at the ethanol country par preference: Brazil. Figure 15 shows a considerable levelling out of total emissions, but it is followed by huge increases, mirroring the GDP development.

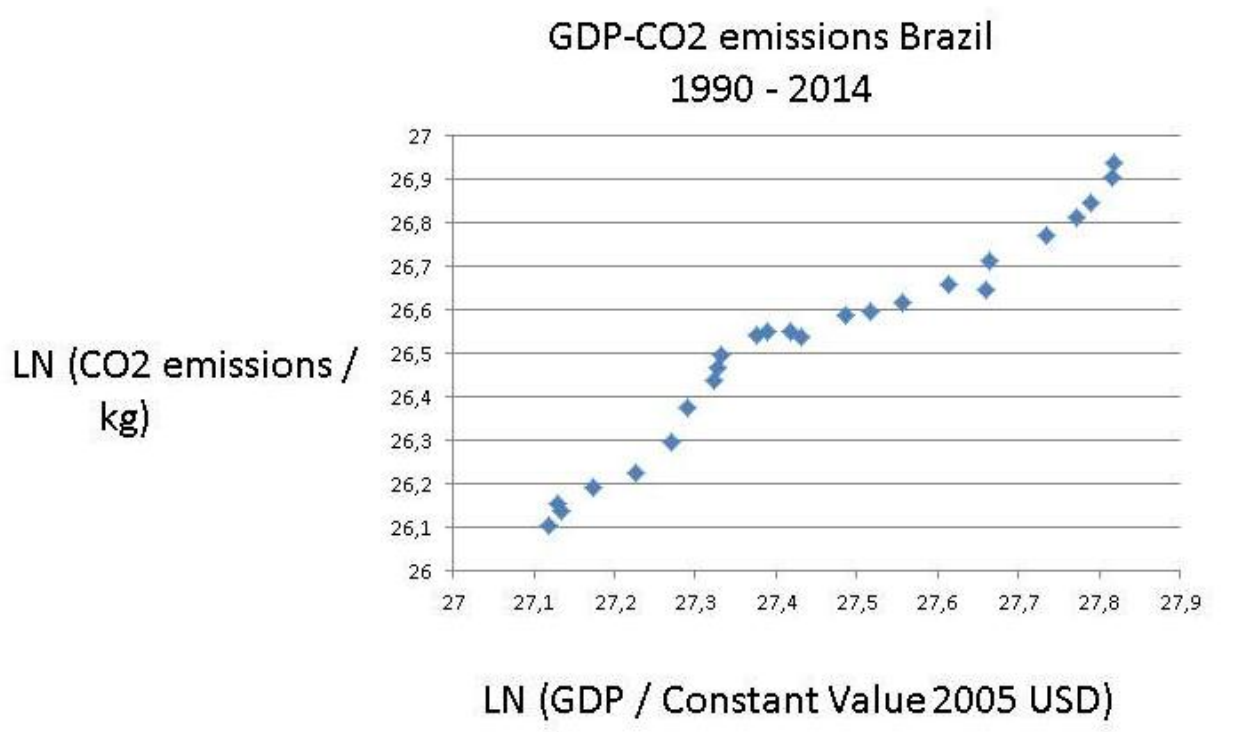

Figure 15. BRAZIL: LN (CO2 / Kg and LN (GDP / Constant Value 2005 USD) ( $\mathrm{y}=1,029 \mathrm{x}-1,72 ; \mathrm{R}^{2}=0,95$ )

Brazil employs the most biomass in the world - ethanol, but the emissions stay at a very high level, which is a reminder that renewables may also lead to $\mathrm{CO} 2$ :s. One advantage for Brazil is the large component of hydro power, but the overall picture for the largest Latin American country is not wholly promising, when it comes to reduction of emissions. Yet, global warming reduces the potential of hydro power, and Brazil has very little nuclear power (Figure 16). There are plans for mega hydro projects in the Amazon basin, but Brazil has first and foremost to come to terms with the extensive deforestation of this huge rain forest, contributing a lot to global warming. 


\section{Brazil energy consumption 2013}

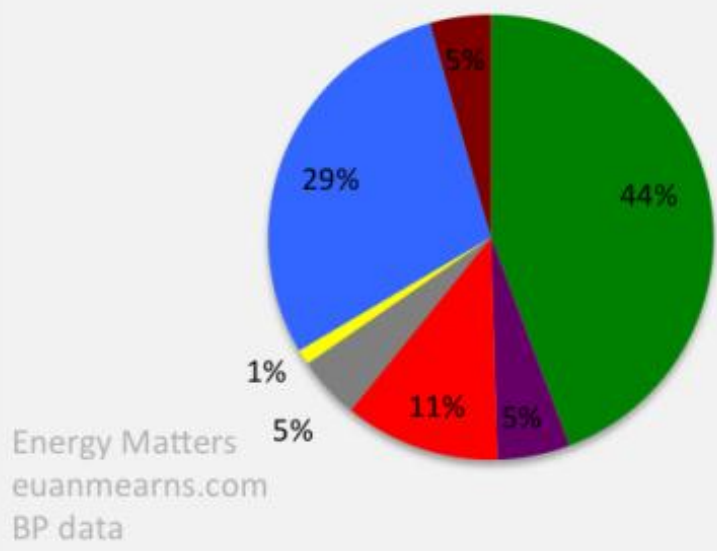

Oil

- Biofuel

Gas

Coal

Nuclear

Hydro

Renewables

Figure 16.

I believe most "emerging economies" rely much upon fossil fuels, like the examples above. Bur how about some "mature economies".

\section{Post-Modern Societies}

Although Canada is a major emitter of CO2:s as well as one of the world's largest fossil fuel producer - oil sands, it has managed to stem the increase in emissions for the most recent years, i.e. halting the augmentation (Figure 17). Its energy mix may be invoked to explain this, showing a very mixed energy consumption pattern.

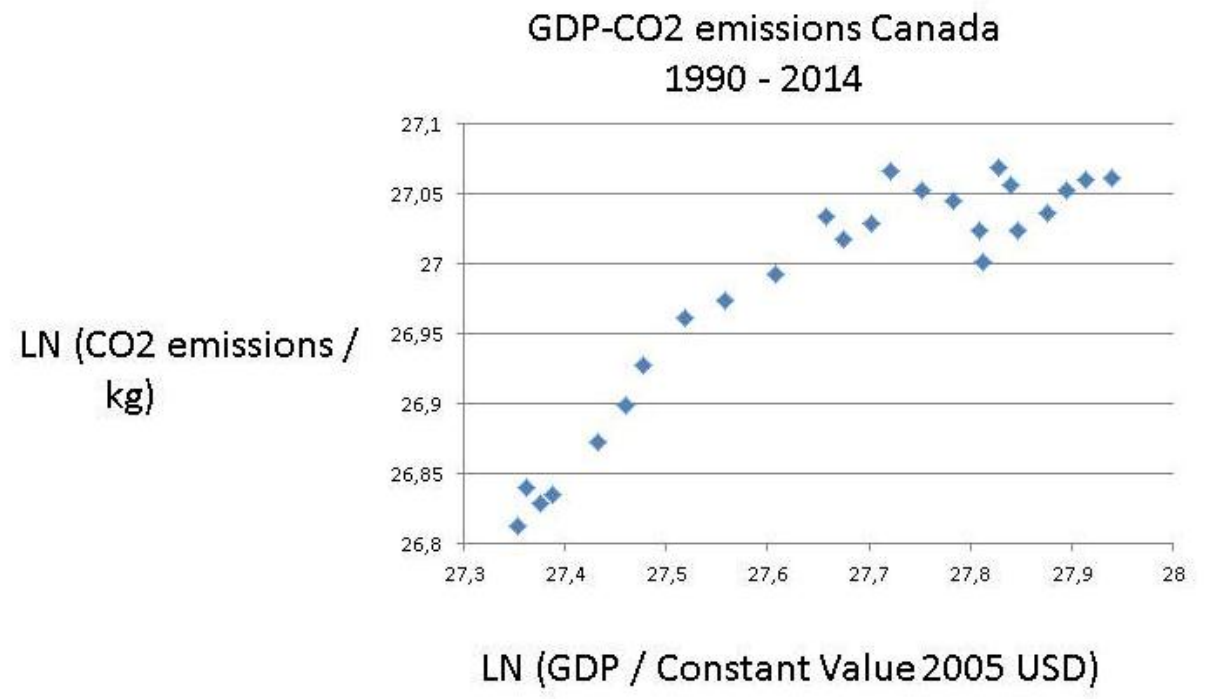

Figure 17. Canada: LN (CO2 / Kg and LN (GDP / Constant Value 2005 USD) $\left(\mathrm{y}=0,41 \mathrm{x}+15,7 ; \mathrm{R}^{2}=0,85\right)$

Correctly, Canada has HALTED but not REDUCED CO2 emissions. There is often this confusion about $\mathrm{CO} 2$ emissions. To start reducing emissions, Canada may wish to eliminate coal and increase nuclear or renewables (Figure 18). 


\section{Canadian Energy Consumption by Primary Type}

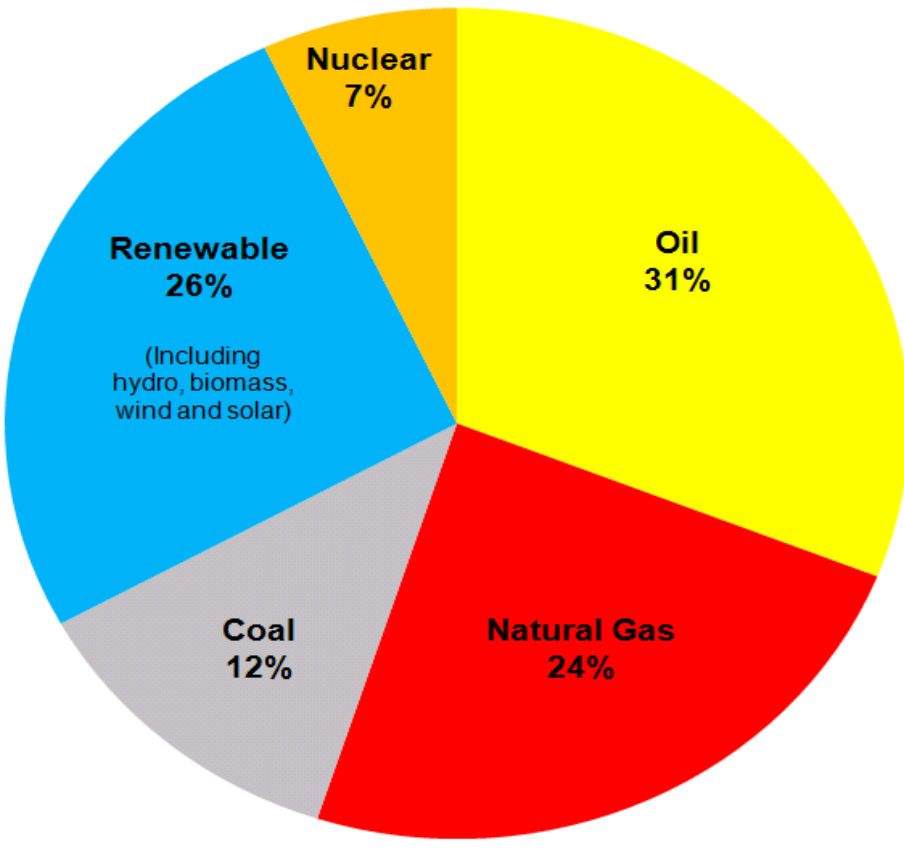

Data source: Foreign Affairs and International Trade Canada, 2006

Figure 18.

Canada has a strong advantage compared with for instance China and India in that it has access to lots of hydro power and natural gas. The burning of coal is as low as 12 per cent, but oil still makes up almost a third of energy consumption.

\subsection{The US}

For most countries hold that their emission of $\mathrm{CO} 2$ :s increases, as well as augments with the GDP. However, there are a few notable exceptions of decreases that are worth mentioning among the mature economies. We start with the US (Figure 19).

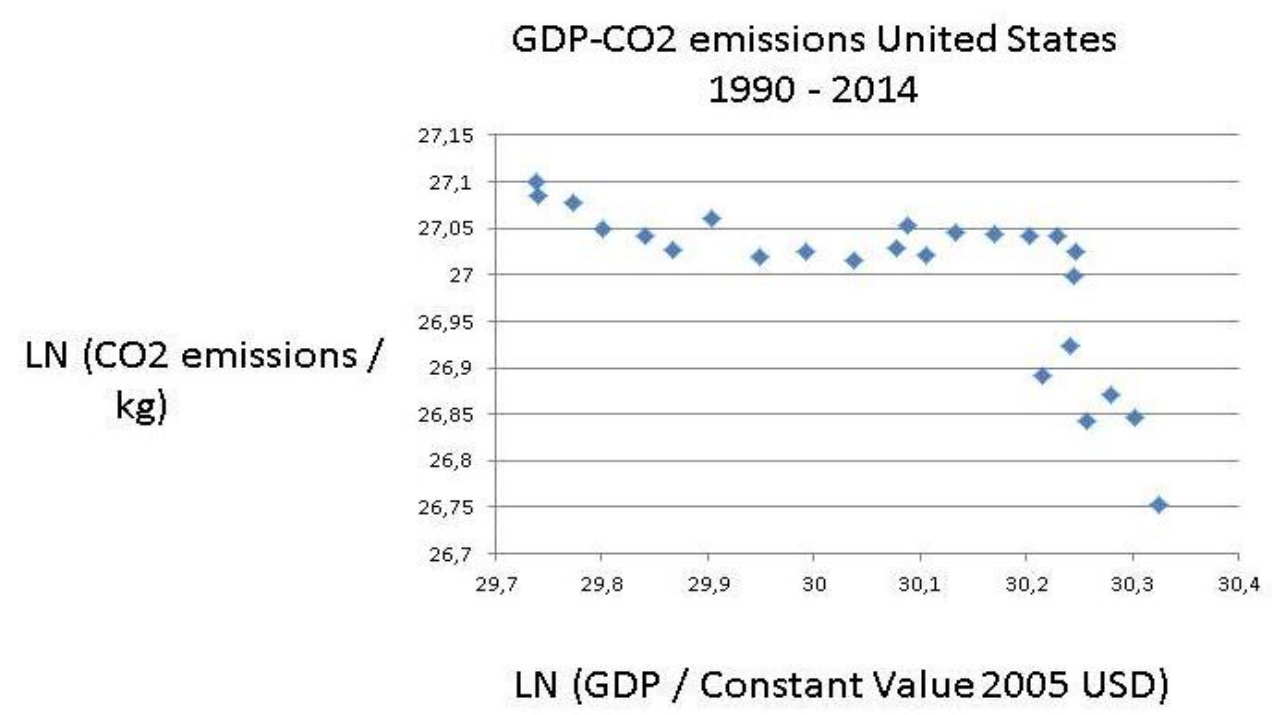

Figure 19. USA: LN (CO2 / Kg And LN (GDP / Constant Value 2005 USD) ( $\mathrm{Y}=-0,32 \mathrm{x}+36,7 ; \mathrm{R}^{2}=0,49$ ) Recently, the level of $\mathrm{CO} 2$ emission has been reduced significantly in the US. It reflects no doubt partly the economic 
crisis that began 2007, but the US remains the second largest polluter in the world. The reduction reflects that the US can draw upon a mixed bag of energies including nuclear and hydro power, with solar power expanding rapidly (Figure 20). Per capita CO2:s is of course very high for the USA. As the economy now starts to accelerate, emissions are bound to go up again, unless solar power stations multiply dramatically over the country.

\section{Primary energy consumption by source and sector, 2014 quadrilion Btu}

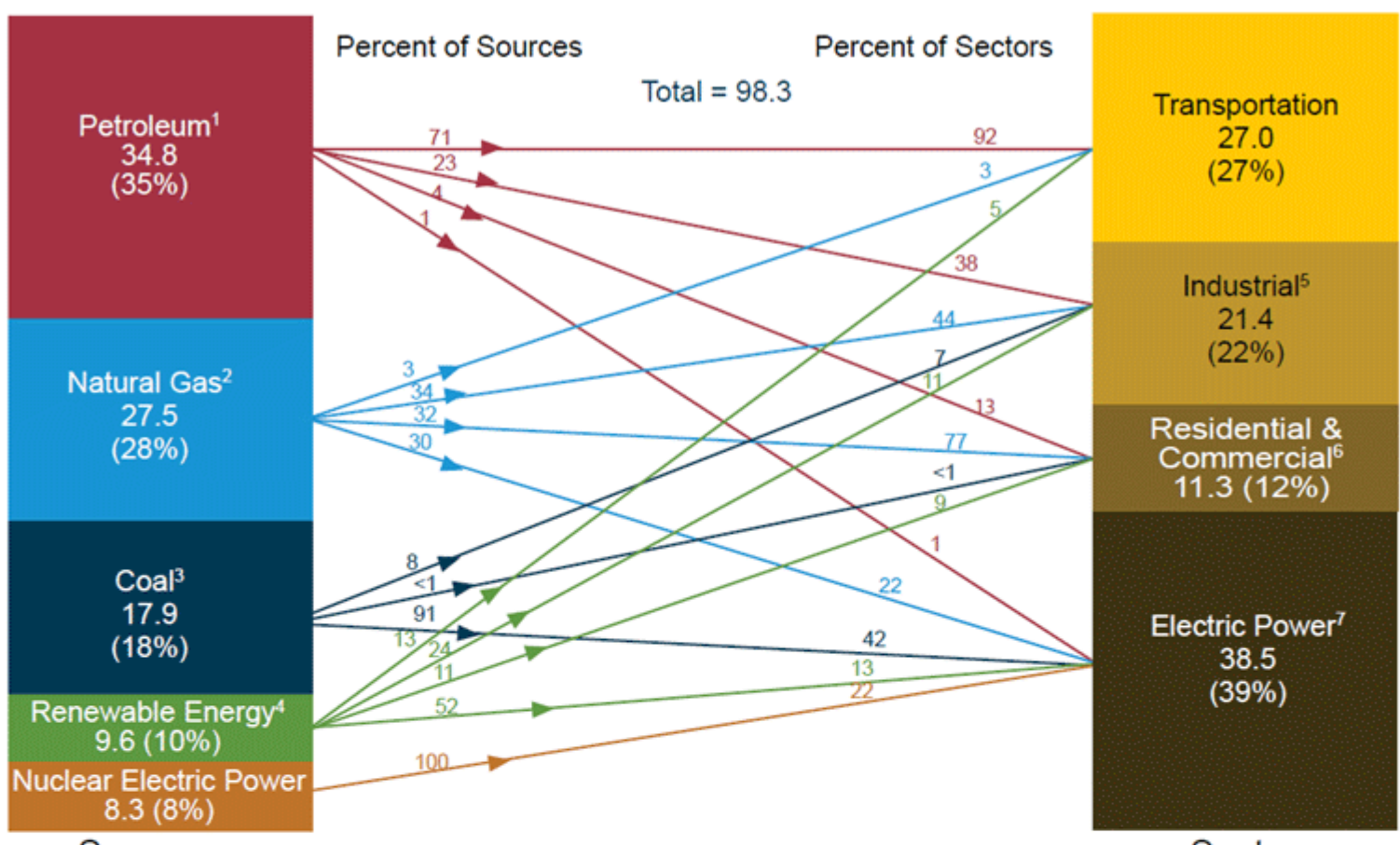

Source

Sector

\section{Endnotes:}

${ }^{1}$ Does not include biofuels that have been blended with petroleum—biofuels are included in

"Renewable Energy."

${ }^{2}$ Excludes supplemental gaseous fuels.

${ }^{3}$ Includes less than -0.1 quadrillion Btu of coal coke net imports.

${ }^{4}$ Conventional hydroelectric power, geothermal, solar/photovoltaic, wind, and biomass.

${ }^{5}$ Includes industrial combined-heat-and-power (CHP) and industrial electricity-only plants.

${ }^{6}$ Includes commercial combined-heat-and-power (CHP) and commercial electricity-only plants.

${ }^{7}$ Electricity-only and combined-heat-and-power (CHP) plants whose primary business is to sell electricity, or electricity and heat, to the public. Includes 0.2 quadrillion Btu of electricity net imports not shown under "Source."

Notes: Primary energy in the form that it is first accounted for in a statistical energy balance, before any transformation to secondary or tertiary forms of energy (for example, coal is used to generate electricity). - Sum of components may not equal total due to independent rounding.

Sources: U.S. Energy Information Administration, Monthly Energy Review (March 2015), Tables 1.3, 2.1-2.6.

Figure 20.

The US is still heavily dependent upon fossil fuels, or some 80 per cent comes there from. What is changing is the more and more of energy is produced within the US and no longer imported from outside - the shake oil and gas revolution. Further reduction of $\mathrm{CO} 2$ :s may meet with firm resistance from the Republican House of Congress, which may oppose the COP21 Agreement. However, solar power should be attractive in many US states, both in micro use in households and large plant use. 
The advent of shale oil and gas has changed the entire energy markets, lowering the price of oil most substantially. This implies not only that there will be no Hubbert peak oil for the world, but also that switching to renewable energy source will be extremely expensive, relatively speaking compared with shale oil and gas. When petroleum is abundant, then investments in carbon neutral power sources may be non-lucrative and require massive state subsidies.

Figure 20 shows how important energy is to the entire US society, including for its superpower position. When further reductions in $\mathrm{CO} 2$ :s threaten vital national interests, the US like other nations will no doubt employ fossil fuels.

\subsection{Germany}

Another interesting country is the largest EU economy, namely Germany. Figure 21 shows a marked decrease in CO2 emissions.

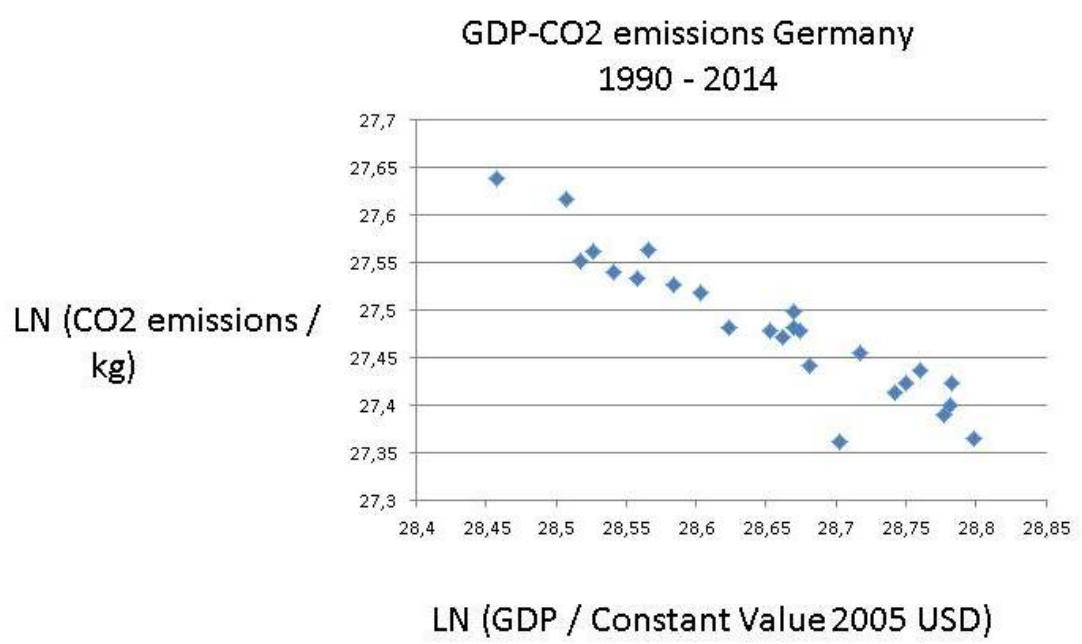

Figure 21. Germany: LN (CO2 / Kg and LN (GDP / Constant Value 2005 USD) $\left(y=-0,69 x+47,3 ; R^{2}=0,88\right)$

The German data shows an impressively consistent decreasing trend, which is not to be found with many countries, if at all. How come that Germany has succeeded in a short time span to reduce CO2:s? Germany needs massive amounts of energy for industry and transportation, but it has decided to phase out nuclear power. Can really the domestic employment of renewables satisfy this giant's demand for electricity German energy policy - ENERGIWENDE - is spectacular comparatively speaking, but it also appears risky indeed. Another country with decreasing greenhouse gasesis Sweden, benefitting from hydro power and nuclear power besides wind power (Figure 22). 
Sweden GDP - GHG 1990 - 2011

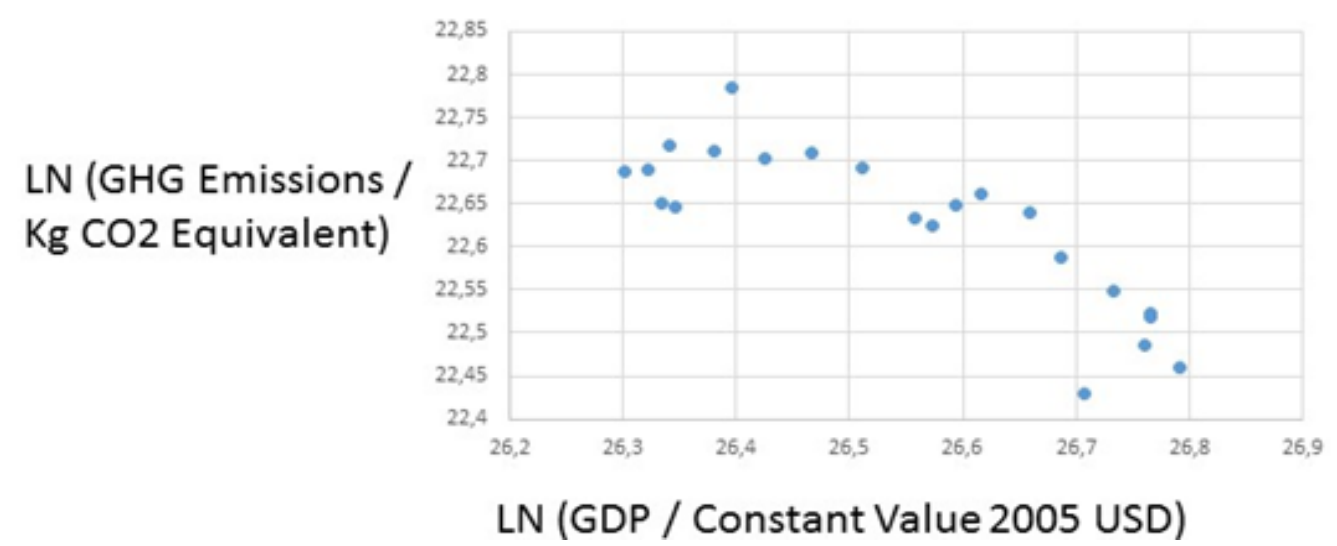

Figure 22. GDP-GHC emissions for Sweden

It is true that nuclear power and renewables has made it possible for Germany to decrease its CO2:s much, but the country is still dependent upon fossil fuels, especially coal and oil - almost $60 \%$. What will happen with the nuclear power stations are phased out in 2022 is that most likely the $\mathrm{CO} 2$ emissions will start going up again. To replace nuclear power with solar and wind power on a truly massive scale will be difficult to say the least. Already, Germany uses more coal from Columbia and gas from Russia.

The German energy policy is causing much stir, because the losers - nuclear industry and coal power interests - want compensation that will run into billions of dollars, if not more.

\subsection{France}

Interestingly, also France has like Germany managed decarbonisation to some extent (Figure 23). It reflects its unique energy mix, relying much upon nuclear power in a comparatively unique way.

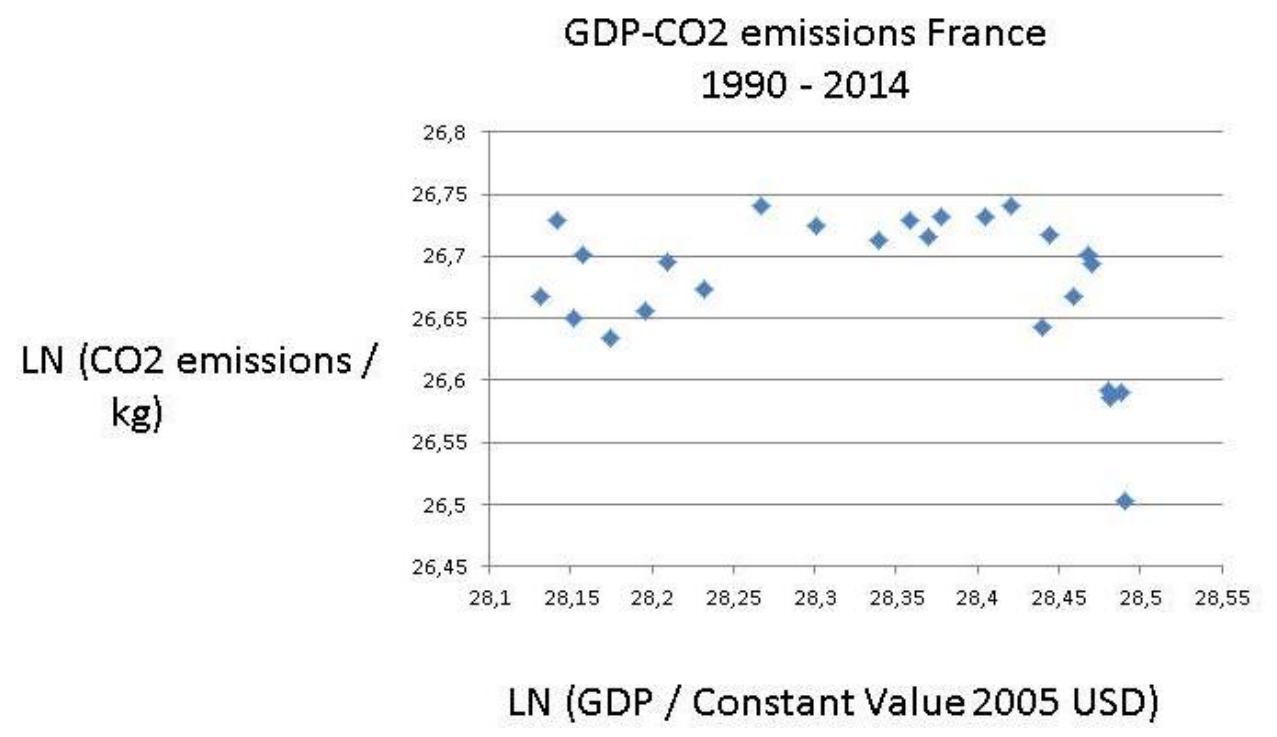

Figure 23-1. France $\left(y=-0,13 x+30,4 ; R^{2}=0,08\right)$

Yet, France has decided to diminish its reliance upon nuclear power. But how will it be replaced by other sources of energy? Figure 23 infroms about the reliance upon fossil fuels in France too. 


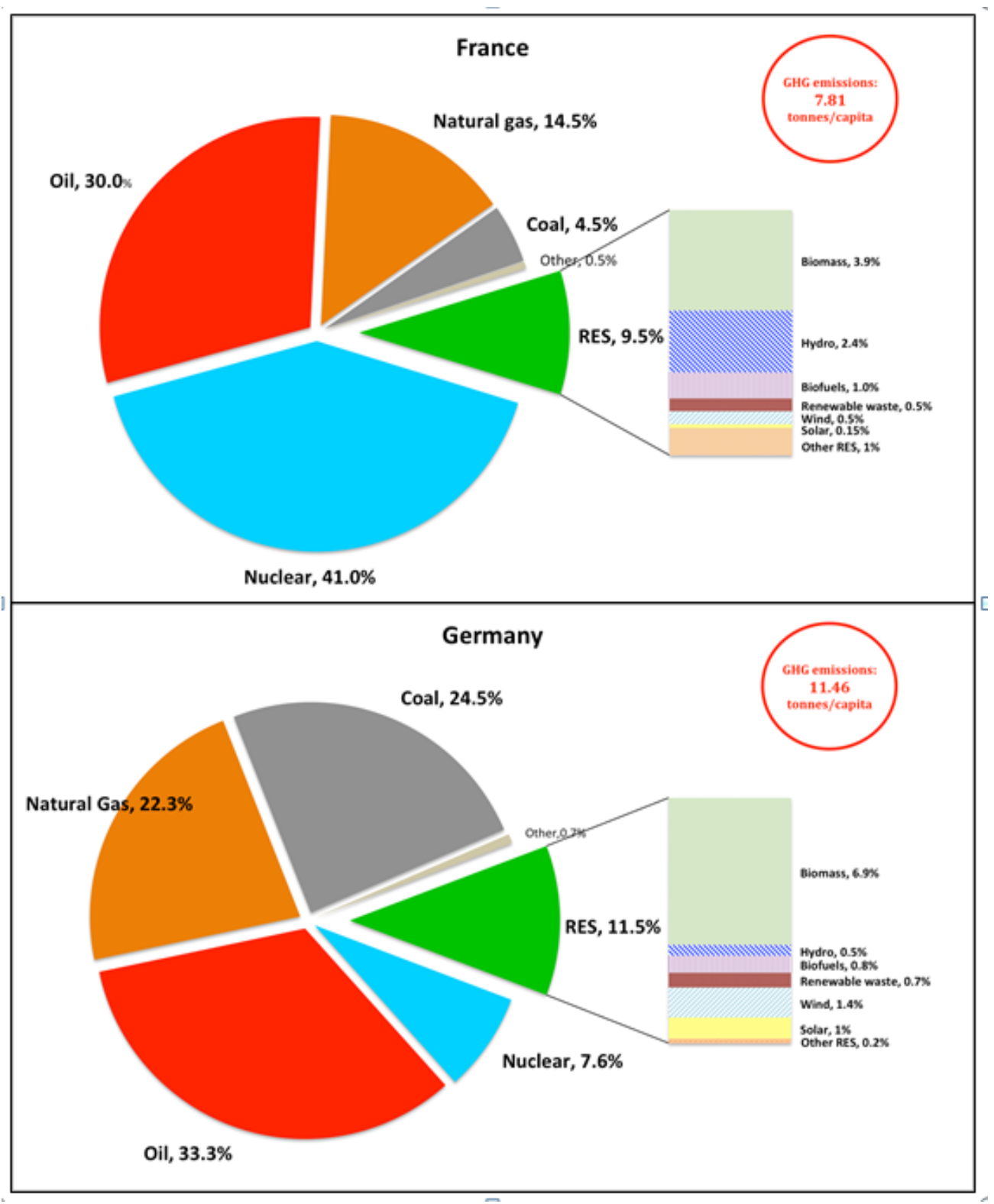

Figure 23-2.

Source: http://blog.iass-potsdam.de/2015/05/energy-transition-france-following-in-germanys-footsteps/

As underlined, no other country in the world employs nuclear power to such an extent (Figure 23), allowing France to avoid lost of CO2:s. But the Green movement's criticism of nuclear power is based upon entirely different argument than the wish to decarbonise economy and society. Actually, doing both - decarbonisation and de-nuclearisation - may prove difficult for France. The French energy sector - EDF and AREVA - has suffered immensely from lower energy prices and scepticism about nuclear power, requiring massive state support.

\section{4 "Green States"}

The states around the Persian Gulf - kingdoms and emirates - have advanced economies, producing large amounts of $\mathrm{CO} 2 \mathrm{~s}$ - see Figure 24 for Saudi Arabia. However, they also wish to demonstrate a green ambition. 


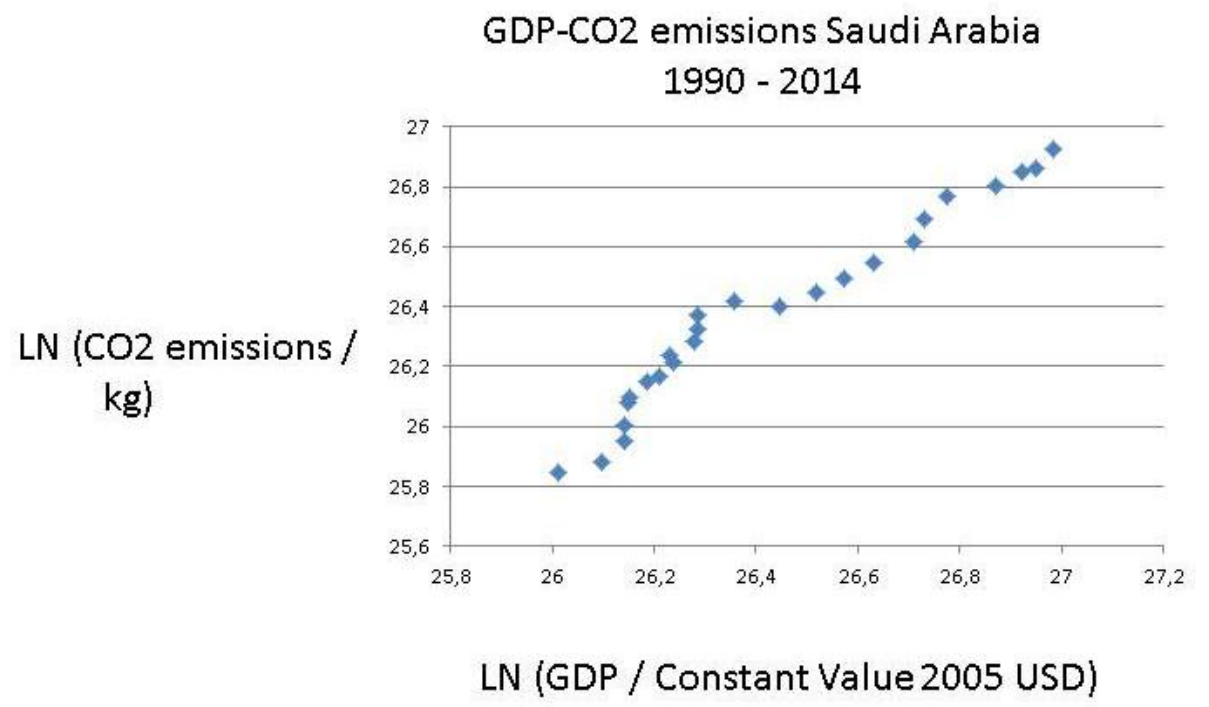

Figure 24. Saudi Arabia $\quad\left(y=1,03 x-0,77 ; R^{2}=0,95\right)$

The Saudis like the Emirates rely upon two kinds of fossil fuels, oil and gas (Figure 25). And they use lots of cement for their magnificent buildings, like Dubai and Abu Dhabi.

\section{Total Energy Consumption in Saudi Arabia, by Type}

(2008)

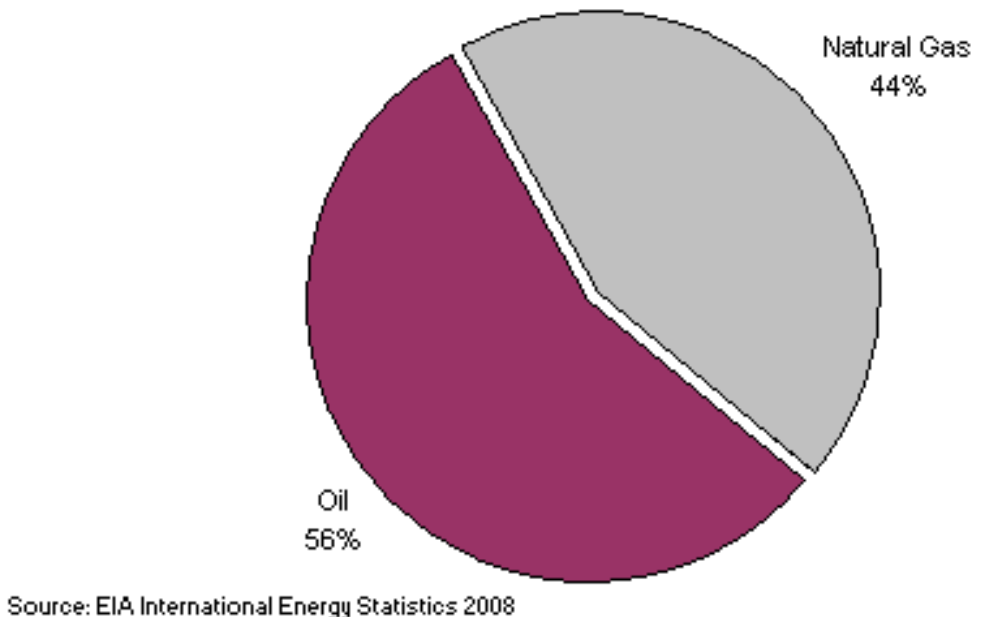

Figure 25 .

Moreover, the UAE have increased their emission of $\mathrm{CO} 2$ sharply in relation the positive economic development of these emirates. They rely upon the fossil fuels of Abu Dhabi with immense oil resources. Like other Gulf States, the UAE boosts with building entirely GREEN sites, with energy from solar power and resulting in almost no waste. But it is based upon their enormous consumption of electricity, generated out of burning oil and gas.

\subsection{Poor Countries}

One may guess correctly that countries that try hard to "catch-up" will have increasing emissions. This was true of China and India. Let us look at three more examples, like e.g. giant Indonesia - now the fourth largest emitter of CO2:s in the world. 


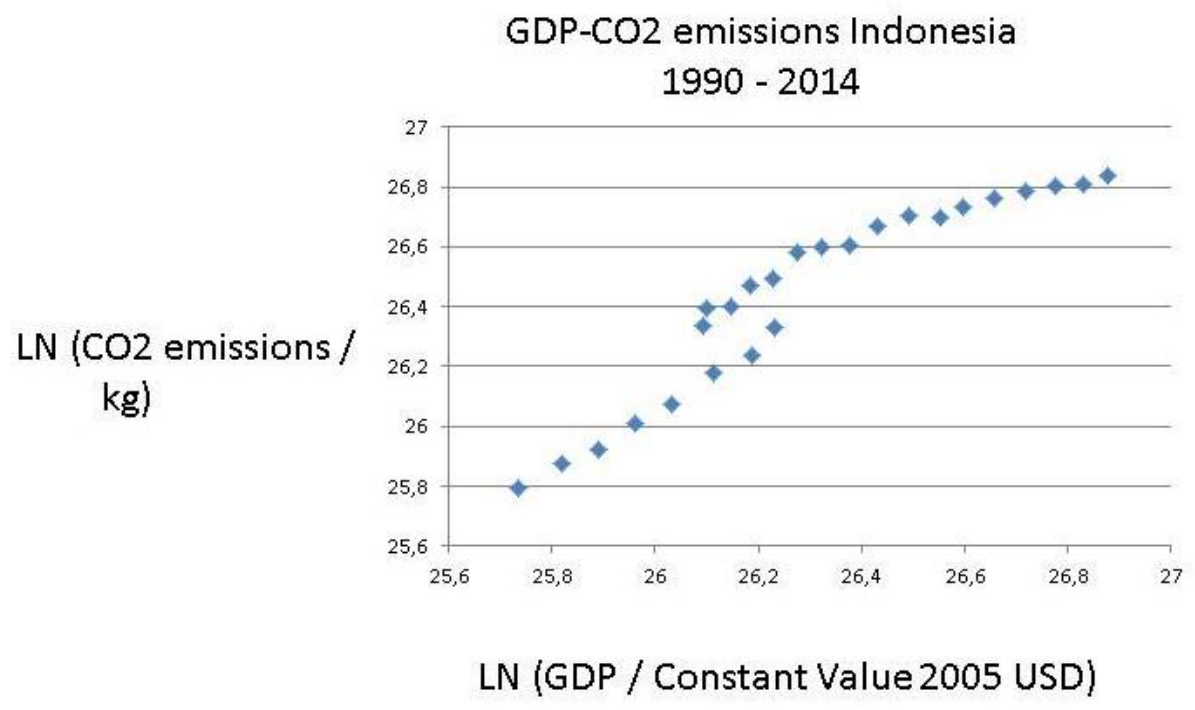

Figure 24. Indonesia: LN (CO2 / Kg and LN (GDP / Constant Value 2005 USD) y $=0,95 x+1,58 ; \mathrm{R}^{2}=0,89$

Indonesia is a coming giant, both economically and sadly in terms of pollution. Figure 9 reminds of the upward trend for China and India. However, matters are even worse for Indonesia, as the burning of the rain forest on Kalimantan augments the $\mathrm{CO} 2$ emissions very much. Figure 9 presents the energy mix for this huge country in terms of population and territory.

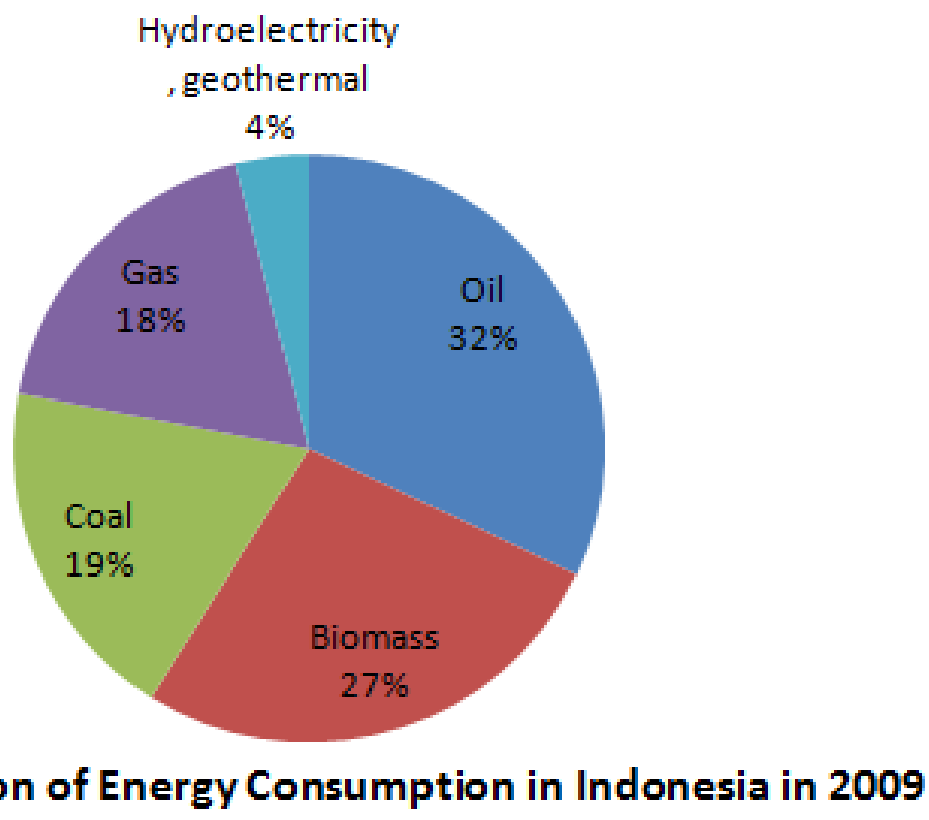

Figure 25. Indonesia

Source: (http://missrifka.com/energy-issue/recent-energy-status-in-indonesia.html)

Only 4 per cent comes from hydro power with 70 per cent from fossil fuels and the remaining 27 per cent from biomass, which alas also pollutes.

The same upward trend holds for another poor developing country with huge population, namely Pakistan (Figure 26). 


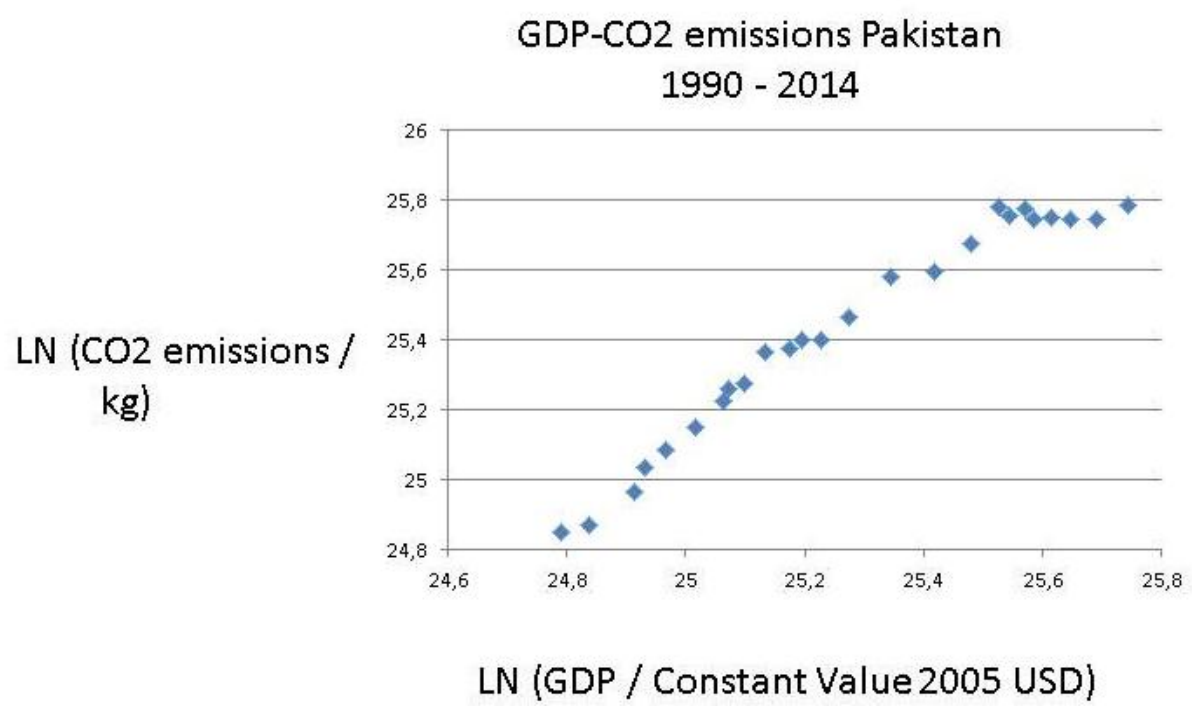

Figure 26. Pakistan: LN (CO2 / Kg and LN (GDP / Constant Value 2005 USD) (y= 1,05x - 0,97; R²=0,96)

The amount of $\mathrm{CO} 2$ emissions is high for Pakistan, viewed as aggregate. Pakistan is mainly reliant upon fossil fuels, but not coal among them (Figure 27). Actually, it has a rather mixed bag of energy sources.

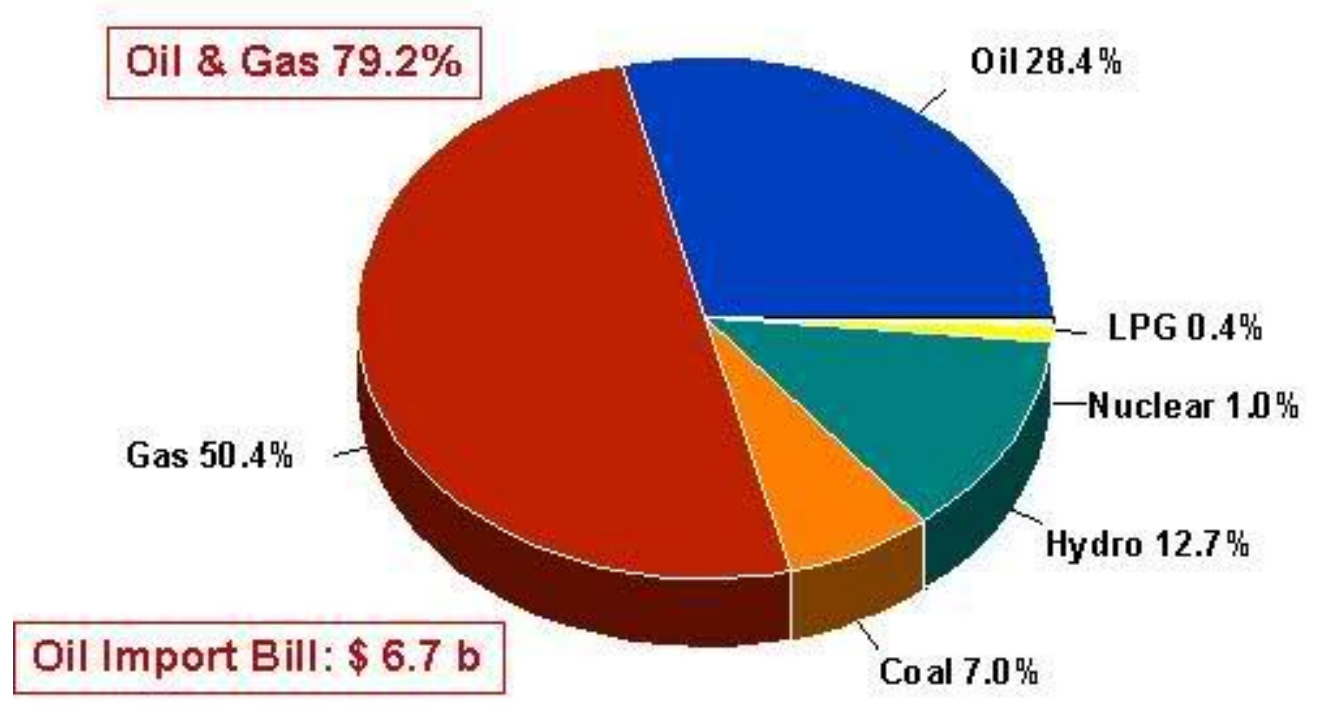

Figure 27. Pakistan Energy Consumption 2009 (by ShoXee: http://i27.tinypic.com/2h6cyag.jpg)

But Pakistan employs a considerable portion of hydropower - 13 per cent - and a minor portion of nuclear power. Can it further develop nuclear and hydro power, or start using solar power on a large scale?

For both poor and rich countries hold that the less they are only dependent upon fossil fuels, the more likely is a transition to an economy resulting in less CO2:s. South Africa for instance is almost exclusively dependent upon coal, which is highly polluting, despite the fact that solar power is feasible in this part of Africa. When a country has access to hydro or nuclear power, it certainly helps reducing emissions from electricity production. But no country has found a response to the ever swelling use of oil in transportation. If electricity cars replace petrol or diesel cars, then how will electricity be generated in a carbon neutral way?

\section{Towards Green Economic Growth}

Scholars who argue that we can have both decarbonisation and economic growth bet upon the arrival of both more energy efficient technologies and technological innovations that lead to more energy but have little emissions of greenhouse gases. Thus, nuclear power plants can be built in such a way that the risk of a melt-down is excluded. And 
solar power gets all the time cheaper and more reliable.

Yet, in relation to the COP21 Agreement there is cause for much pessimism. It is true that small changes are feasible, replacing fossil fuels with renewables, but we are talking about the need for large scale transformation. See a standard prediction for energy demand in Figure 28.

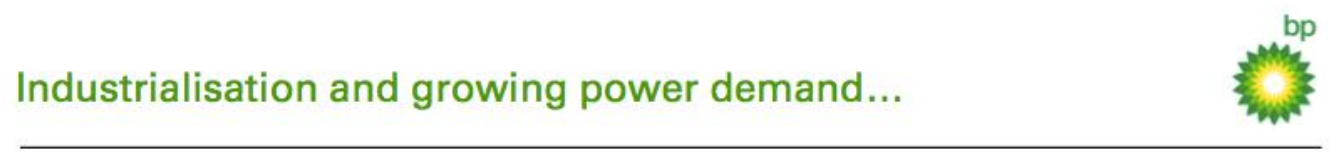

\section{$\begin{array}{lll}\text { By region } & \text { By primary use } & \text { By fuel }\end{array}$}

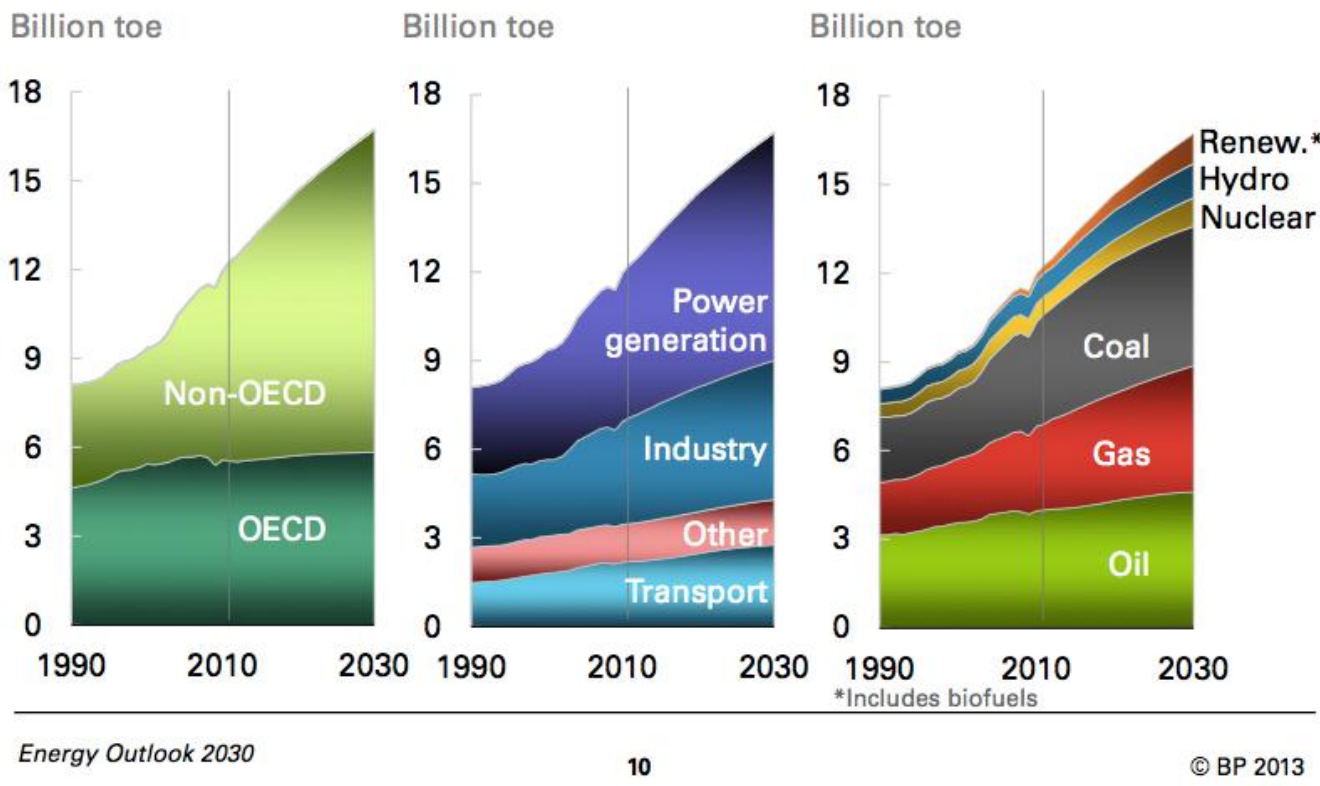

Figure 28.

Source: https://therationalpessimist.com/tag/bp-energy-outlook-2030/

These projections for 2030, the year of COP21, are completely outside of its objectives of a $40 \%$ reduction of $\mathrm{CO} 2$ emissions.

The CO2:s can only be reduced through decarbonisation of the economy in a wide, which can be promoted through:

- A zero growth economy or "sustainable economy" with Sachs, but it is not likely to occur;

- A massive transition to solar, wind and nuclear power, which would require enormous new investments. Large scale solar and wind power needs huge space and are vulnerable to sabotage;

- A reduction in global output, meaning recessions. It will be avoided by governments by all means necessary.

The link between economic growth and environmental protection has been much debated in public policy and environmental economics. One may identify four positions:

- $\quad$ Positive: growth makes environmental protection feasible - rapid growth promotes environmental care;

- Negative: economic development uses up environmental resources or assets - zero growth economy;

- Contingency: it depends upon the particular project whether the impact is positive or negative;

- Trade-off: often development projects result in some economic gains against some environmental losses.

Examining the literature, one finds scholars advocating all four positions (Managi, 2015; Sachs, 2015; Eriksson, 2012; de Bryun, 2012). Probably one can find examples of all four types of combination between growth and environment in all countries: e.g. Indian solar panel parks, Chengdu Park for pandas, Jakarta harbour protection wall, opening up coal mines in tiger sanctuaries in India, burning down the rain forest in Kalimantan for agriculture, building the enormous dam - Three Gorges Dam in China, etc. But, as Indian expert Ramesh (2015) underlines, the question of emissions, energy and economic development involves a trade-off between environment and growth. One may certainly fear that many governments will renege upon COP21 when faced with a choice between economic growth and green sustainability. 


\section{Reference}

De-Bruyn, S. M. (2012). Economic Growth and the Environment: An Empirical Analysis. Berlin: Springer. Energy Information Administration. Washington, DC.

Eriksson, C. (2013) Economic Growth and the Environment: An Introduction to the Theory. Oxford: OUP. http://dx.doi.org/10.1093/acprof:osobl/9780199663897.001.0001

EU Joint Research Centre Emission Database for Global Atmospheric Research http://edgar.jrc.ec.europa.eu/overview.php Eurostat: Demographic Statistics

Global Footprint Network. https://www.google.com/?client=gmail\#q=global\%20footprint\%20network\&authuser=0 International Energy Agency. Paris.

Living Planet Report (2008). GFF. The Ecological Footprint Atlas 2008.

Living Planet Report (2014). Global Footprint Network, WWF, Zoological Society of London.

Managi, S. (2015). The Routledge Handbook of Environmental Economics in Asia. London: Routledge.

Mazmanian, D. A., \& Sabatier, P. A. (1989). Implementation and Public Policy Paperback. Lanham, MD: UPA. OECD National Accounts data files Population and Vital Statistics Report (various years), Census

Pressman, J., \& Wildavsky, A. (1984). Implementation. Berkeley: University of California Press. reports and other statistical publications from national statistical

Sachs, J. (2015). Sustainable Development for Humanity’s Future. http://jeffsachs.org/2015/08/sustainable-development-for-humanitys-future/

Sachs, J. D. (2015). The Age of Sustainable Development. New York: Columbia University Press. Secretariat of the Pacific Community: Statistics and Demography Programme,

Stern, N. (2007). The Economics of Climate Change. Oxford: OUP. http://dx.doi.org/10.1017/CBO9780511817434 U.S.Census Bureau: International Database

UN Framework Convention on Climate Change http://unfccc.int/ghg_data/ghg_data_unfccc/time_series_annex_i/items/3814.php United Nations Population Division.

Wildavsky, A. (1987). Speaking Truth to Power. 2ond ed. Piscataway :Transaction Publishers.

Williamson, O. (1973). Hierarchies and Markets. New York : Free Press.

World Bank national accounts data - data.worldbank.org

World Population Prospects, United Nations Statistical Division.

World Resources Institute CAIT Climate Data Explorer. cait.wri.org

\section{(cc) $\mathrm{Br}$}

This work is licensed under a Creative Commons Attribution 3.0 License. 